\title{
An Overview of Consumer Data and Credit Reporting
}

Robert B. Avery, Paul S. Calem, and Glenn B. Canner, of the Board's Division of Research and Statistics, and Raphael W. Bostic, of the University: of Southern California, prepared this article.

For some time, the Board of Governors of the Federal Reserve System has sought to obtain more detailed and timely information on the debt status, loan payment behavior, and overall credit quality of U.S. consumers. Such information could facilitate the Board's analysis of macroeconomic conditions, improve its understanding of the way credit is provided to consumers, and enhance the System's supervision of banking activities. For decades, information of this type has been gathered by credit reporting companies, primarily to assist creditors in evaluating the credit quality of current and prospective customers. The information gathered by credit reporting companies is vast and seeks to cover virtually all U.S. consumer borrowing. ${ }^{1}$ To the extent that this information is complete, comprehensive, and accurate, it represents a potential new source of statistical data for the Federal Reserve on consumer credit markets and behavior.

To evaluate the potential usefulness of these data, the Federal Reserve Board engaged one of the three national credit reporting companies to supply the records of a nationally representative sample of individuals. ${ }^{2}$ The data provide a unique opportunity

1. The Fair Credit Reporting Act generally refers to a company that regularly assembles or evaluates consumer credit information for the purpose of furnishing consumer reports as a "consumer reporting agency." Such companies are also called "credit bureaus" or, as in this article, "credit reporting companies." Three national credit reporting companies-Equifax, Experian, and Trans Union Corporationjointly have a dominant presence in the market for credit-related information on consumers. Each national credit reporting company seeks to maintain records for each individual, although, for a variety of reasons, all companies may not have the same information for a given individual. For more information on industry structure, see Robert M. Hunt, "What's in the File? The Economics and Law of Consumer Credit Bureaus," Business Review, Federal Reserve Bank of Philadelphia (second quarter, 2002), pp. 17-24.

2. Identifying information, such as name, address, and social security number, was omitted from the data obtained by the Federal Reserve. The identities of the creditors, collection agencies, and other to profile the nature and content of information contained in credit reporting company records.

Assessing the usefulness of these data as a potential source of information for the Board involves several tasks. This article is an initial step in the process; it examines the scope and content of the data, using a framework based on key aspects of credit evaluation. This approach is a natural way to begin the assessment process because the credit reporting companies' primary purpose for collecting these data is to facilitate credit evaluation. Future steps will focus on other aspects of this evaluation, including comparing measures of aggregate borrowing activity and credit quality derived from the credit reporting data with measures from other sources.

The article begins with a brief description of the way the credit reporting companies compile and report their data and gives background on the regulatory structure governing these activities. This description is followed by a detailed look at the information collected in credit reports. The discussion of these data is divided along the lines of the major components of consumer credit report data-credit accounts; public records relating to the person's debt or payment obligations (bankruptcy filings, liens, judgments in civil actions, and so on); collection agency accounts; and inquiries regarding credit status. The distribution patterns of items such as account balances, credit utilization, and measures of payment performance by type of account and creditor are broadly described. Key aspects of the data that may be incomplete, duplicative, or ambiguous as they apply to credit evaluation are highlighted in the analysis. The article concludes with a discussion of steps that might be taken to address some of the issues identified.

entities that reported information to the credit reporting company were also omitted. An index variable, unique to this dataset, allowed records of the same individual to be linked. A similar index variable allowed records of the same creditor (or other reporter) to be linked. Neither of these variables could be used to link to any publicly available information. 


\section{COMPOSITION'AND SOURCES OF CREDIT. REPORTING COMPANY RECORDS}

Credit reporting companies gather information on an individual's experiences with credit, leases, noncredit-related bills, money-related public records, and inquiries and compile it in a credit record. A credit record generally includes five types of information:

- identifying information such as the name of the individual, current and previous residential addresses, and social security number

- detailed information reported by creditors (and some other entities, such as a medical establishment) on each current and past loan, lease, or non-creditrelated bill, each of which is referred to here as a credit account $^{3}$

- information derived from money-related public records, such as records of bankruptcy, foreclosure, tax liens (local, state, or federal), garnishments, and other civil judgments, referred to here as public records

3. Non-credit-related bills include items such as utility and medical bills.
- information reported by collection agencies on actions associated with credit accounts and noncredit-related bills, referred to here as collection agency accounts

- identities of individuals or companies that request information from an individual's credit record, the date of the inquiry, and an indication of whether the inquiry was by the consumer, for the review of an existing account, or to help the inquirer make a decision on a potential future account or relationship.

The consumer credit report, the basic product that the credit reporting companies provide to those seeking information about the credit history of an individual, is the organized presentation of the individual's credit record at the credit reporting company. ${ }^{4}$ Industry sources report that credit reporting companies issue approximately 2 million consumer credit

4. Credit reporting companies maintain credit records of individuals, not couples or other family units. Therefore, an individual's credit report is separate and distinct from his or her spouse's report. If individuals are jointly responsible for payment on a loan, such as a mortgage, a record of that credit account will appear in each individual's file, along with an indicator that it is a joint account.

\section{A Summary of Consumer Rights under the Fair Credit Reporting Act}

The federal Fair Credit Reporting Act (FCRA) seeks to promote accuracy, fairness, and privacy of an individual's "consumer report" maintained by a "consumer reporting agency" (or credit reporting company).' The FCRA provides the following consumer rights and protections:

- The right to be told if information in a consumer report has been used to take adverse action against a consumer. Any person who uses information from a consumer report obtained from a consumer reporting agency to take adverse action against a consumer - such as denying an application for credit, insurance, or employment - must tell the consumer the name, address, and phone number of the reporting agency that provided the consumer report, inform the consumer of the right to obtain a free copy of his or her consumer report within sixty days of receiving the notice, and notify the consumer of the right to dispute with the reporting agency the completeness or accuracy of the consumer report.

- The right to see the contents of a consumer report. Upon a consumer's request, a consumer reporting agency must provide the consumer with all information in his or her file at the time of the request, except for credit scores,

1. For the complete text of the FCRA, see 15 U.S.C. $\S \S 1681-1681 \mathrm{u}$, on the Federal Trade Commission's web site (http:/www.ftc.gov). and identify each person who has requested it recently. There is no charge for the report if an adverse action has been taken against the consumer because of information in a consumer report supplied by the reporting agency and the consumer requests the report within sixty days of receiving notice of the adverse action from the person taking the adverse action.

- The right to dispute inaccurate or incomplete information with the consumer reporting agency. If a consumer notifies a reporting agency that his or her file contains inaccurate or incomplete information, the agency must investigate the items (generally within thirty days) by presenting to the furnisher or source of the information all relevant evidence submitted by the consumer, unless the agency determines that the dispute is frivolous. The furnisher or source must review the evidence, investigate the disputed information, and report its findings to the reporting agency. The agency must provide the consumer with a written notice of the results of the investigation, a copy of the consumer report as revised based on the results of the investigation, notice of the procedures used in the investigation (including the furnishers contacted), notice of the consumer's right to add a statement to the file disputing the accuracy or completeness of the information, and notice of the consumer's right to request that the reporting agency notify certain recent recipients of consumer reports of the deletion of the disputed information. 
reports each day. ${ }^{5}$ Access to the information and maintenance of each credit record is governed by conditions spelled out in the Fair Credit Reporting Act (FCRA) (see box "A Summary of Consumer Rights under the Fair Credit Reporting Act").

Credit reporting companies gather the information that is in a credit record primarily from creditors, government entities, collection agencies, and third-party intermediaries (see box "Sources of Credit Reporting Company Data"). Reporting entities submit information to credit reporting companies on a purely voluntary basis; no state or federal law requires creditors or others to report data to the companies. The FCRA prohibits a reporting institution from furnishing any information to a credit reporting company if the institution knows or consciously avoids knowing that the information is inaccurate, and it requires institutions to participate in the process of correcting errors that are identified by consumers.

5. See Consumer Data Industry Association (formerly, the Associated Credit Bureaus), Press Release, March 12, 1998.
The national credit reporting companies attempt to collect comprehensive information on all lending to individuals in the United States, and the information each maintains is vast." Each of the three national credit reporting companies has records on perhaps as many as 1.5 billion credit accounts held by approximately 190 million individuals. Credit reporting companies receive information from creditors and others generally every month, and they update their credit records normally within one to seven days of receiving new information. According to industry sources, each of the three national credit reporting companies receives more than 2 billion items of information each month.

Credit reporting companies use various techniques to process the high volume of information they receive. When a credit reporting company receives data from a creditor, government agency, or thirdparty provider, it first assesses its accuracy. If the data are found to contain errors, they are returned to the

6. See "About CDIA" on the web site of the Consumer Data Industry Association, www.cdiaoline.org.

\section{A Summary of Consumer Rights under the Fair Credit Reporting Act-Continued}

- The right to have inaccurate information corrected or deleted. A consumer reporting agency must remove or correct inaccurate, incomplete, or unverified information from its files, generally within thirty days after a dispute is filed. However, the reporting agency is not required to remove accurate data from a consumer's file unless it is outdated information that is required to be excluded from consumer reports.

- The right to dispute inaccurate items with the furnisher or source of the information. If a consumer tells a furnisher ofinformation, such as a creditor who reports to a consumer reporting agency, that specific information is inaccurate or incomplete, the furnisher may not then report the information to a reporting agency without including a notice of the dispute.

- The right to have outdated information excluded from a consumer report. In most cases, a consumer reporting agency may not report negative information that is more than seven years old. However, there are certain exceptions:

- Information about criminal convictions may be reported without any time limitation.

Bankruptcy information may be reported for ten years.

- Information reported in response to an application for a job with an annual salary of more than $\$ 75,000$ has no time limit.

- Information reported because of an application for more than $\$ 150,000$ worth of credit or life insurance has no time limit.
- Information about a lawsuit, an unpaid judgment against a consumer, or record of arrest can be reported for seven years or until the statute of limitations runs out, whichever is longer.

- Limits for access to a consumer report. A consumer reporting agency may furnish a consumer report only to a person with a permissible purpose recognized by the FCRA - usually to consider an application for credit, insurance, employment, housing rental, depository account, or other legitimate business need, or in accordance with the written instructions of the consumer.

- The requirement for consumer consent to furnish reports to employers or to furnish reports containing medical information. A consumer reporting agency may not furnish a consumer report generally to a consumer's employer or prospective employer, or a consumer report containing medical information about the consumer in connection with a credit or insurance transaction, without the consumer's written consent.

- The right to choose to exclude a consumer's name from consumer reporting agency lists for unsolicited firm offers of credit and insurance. Creditors and insurers may use reporting agency file information as the basis for sending unsolicited firm offers of credit or insurance. Such offers must include a toll-free phone number or address established by the agency from whom the creditor or insurer obtained the information and whom the consumer may call or write to have his or her name and address removed from future lists. 


\section{Sources of Credit Reporting Company Data}

Credit reporting companies receive the information that is included in credit records from a wide variety of sources. They receive information on individual credit accounts, which makes up the bulk of the data that they maintain, from virtually all commercial banks, savings associations, and credit unions; from most finance companies; and from major retailers and many other businesses, such oil and gas companies. Some utility and medical companies also report on their accounts.

Credit reporting companies also gather information from many agencies specializing in collections. These collection agencies may be acting on behalf of a claimant, or they may have purchased the rights to an account themselves. Collection agencies report information on accounts in collection, including many non-credit-related bills, such as those associated with medical treatment or services from communication or power companies, as well as some credit accounts.

Collection agency reporting does not represent a full accounting of credit accounts that have gone to collection. Many creditors do their own collections rather than using collection agencies. If these creditors report to the credit reporting companies, such collections will appear as updates to credit account files. However, if the creditor does not report to the credit reporting companies, then these collection actions will not appear in the credit files.

Credit reporting companies also gather information on public records, obtaining the information from the court system, government entities, or third parties. Some of these sources have computerized, comprehensive records; others keep only paper records that require laborintensive transcribing and recording. The former are easily obtained by credit reporting companies whereas the latter are not. Finally, information on inquiries is recorded by the credit reporting companies as the inquiries are made.

reporting entity for resubmission with the necessary corrections. Otherwise, the credit reporting companies compile and reconfigure the newly received data to create or update the record of an individual's credit experiences. This reconfiguration can require a high level of technical sophistication. For example, credit reporting companies have had to develop rules for deciding when to ignore slight variations in personal identifying information and techniques for recognizing that data items with the same identifying information, such as name, may actually be associated with different individuals.

Although credit reporting company data are extensive, they are not complete. First, information on some credit accounts held by individuals is not reported. Some small retail, mortgage, and finance companies and some government agencies do not report to the credit reporting companies. Loans extended by individuals, employers, insurance companies, and foreign entities typically are not reported. Second, complete information is not always provided for each account reported. Sometimes creditors do not report or update information on the credit accounts of borrowers who consistently make their required payments as scheduled. Credit limits established on revolving accounts are sometimes not reported. Also, creditors may not notify the credit reporting company when an account is closed or undergoes other material changes.

The information reported on credit accounts reflects each account's payment status and outstanding balance shortly before it is forwarded to the credit reporting company. Thus, the report is sensitive to the date on which the information is forwarded. For example, a credit account reported to the credit reporting companies on the day after a payment is made and posted to the account will show a smaller balance than one reported to the companies on the day before the payment.

Although credit reporting companies endeavor to maintain high-quality data, the degree to which consumer credit reports are accurate, complete, or consistent across companies is in dispute. A recent study, for example, found evidence of inconsistencies in the information included in individual credit reports across the national credit reporting companies. ${ }^{7}$ An earlier investigation by a consumer organization suggests that as many as one-third of all consumer credit reports may contain errors that could result in the denial of access to credit." A study by Arthur Andersen \& Company argues, however, that such errors may not have material significance regarding access to credit. The Andersen study concluded that only a small proportion of individuals were denied credit on the basis of inaccurate information in their credit reports."

Overall, research and creditor experience has consistently indicated that credit reporting company information, despite any limitations that it may have, generally provides an effective measure of the rela-

7. See "Credit Score Accuracy and Implications for Consumers," report by Consumer Federation of America and the National Credit Reporting Association, December 17, 2002.

8. See "Mistakes Do Happen: Credit Report Errors Mean Consumers Lose," March 1998, on the web site of the U.S. Public Information Research Group, www.uspirg.org/reports.

9. See Consumer Data Industry Association, Press Release, March 12, 1998; also see Robert M. Hunt, "The Development and Regulation of Consumer Credit Reporting in America," Federal Reserve Bank of Philadelphia, Working Paper no. 02-21, November 2002 
tive credit risk posed by prospective borrowers. ${ }^{10}$ Nonetheless, the industry and its critics alike recommend that consumers review their credit reports periodically, especially if they are in the market for new credit, if they have been denied credit, or if their creditor has changed the terms of an account on the basis of credit reporting company information.

\section{DESCRIPTION OF CREDIT REPORTING COMPANY RECORDS}

One of the three national credit reporting companies provided the Federal Reserve with the full credit records (with the exception of personal and creditor identifying information) of a nationally representative sample of individuals as of June 1999.11 Approximately 248,000 individuals included in the database of the national credit reporting company were randomly selected (table 1). ${ }^{12}$ The credit reporting company then provided the Board with the entire credit record of each of these individuals, excluding any identifying information. Each consumer credit record contained possibly more than 350 variables that described consumer credit usage and performance.

The sample contains information on about 2.58 million credit accounts, a number that, by the authors' estimate, translates into approximately 1.43 billion credit accounts in the credit reporting company's full database (table 2, memo item). The authors estimate the aggregate balances owed on the credit accounts in the full database to have been $\$ 6.7$ trillion as of June 30, 1999. Credit accounts were reported by thousands of organizations, including more than 23,000 creditors reporting currently (those providing data at the time the sample was drawn).

10. See Robert B. Avery, Raphael W. Bostic, Paul S. Calem, and Glenn B. Canner, "Credit Risk, Credit Scoring, and the Performance of Home Mortgages," Federal Reserve Bulletin (July 1996), pp. $621-48$.

11. Most credit and other records contained in the credit reporting company files of individuals are common to the three national companies, which have adopted common standards for the reporting and coding of information provided by creditors and others. Nonetheless, some differences remain across companies. Some small institutions do not report to all three companies, and coverage of public records may not be identical. Moreover, differences can arise because of the timing of the receipt and processing of information at each company within a typical reporting cycle. Finally, rules regarding the linkage of reports to a common individual and the treatment of items such as noncurrent data can vary across credit reporting companies.

12. This sample consists of approximately 1 file out of every 657 files from the reporting company; the sampling frame excludes nonindividual accounts, such as small business accounts, and records of deceased persons.
1. Individuals with credit reporting company records, by type of information

\begin{tabular}{|c|c|c|}
\hline Type of information & Number & $\begin{array}{l}\text { Share of sample } \\
\text { (percent) }\end{array}$ \\
\hline Sample size & 248,027 & 100.0 \\
\hline Credit account $\ldots \ldots \ldots \ldots$ & 216,202 & 87.2 \\
\hline Open and active account ${ }^{1}$ & 198,399 & 80.0 \\
\hline No active account $\ldots . .$. . & 12,637 & 5.1 \\
\hline Authorized user only ${ }^{2}$ & 5,166 & 2.1 \\
\hline Public record & 30,478 & 12.3 \\
\hline Collection agency account & 74,888 & 30.2 \\
\hline Inquiry ${ }^{3}$ & 142,905 & 57.6 \\
\hline None of the above & 318 & .1 \\
\hline МЕмо & & \\
\hline $\begin{array}{l}\text { Credit account only } \\
\text { Public record only }\end{array}$ & 63,674 & $\begin{array}{c}25.7 \\
*\end{array}$ \\
\hline Collection agency account only & 25,905 & 10.6 \\
\hline Inquiry only $\ldots \ldots \ldots \ldots \ldots$ & 55 & * \\
\hline Credit account and: & & \\
\hline Public record . . . . . . . . . & $\begin{array}{l}28,534 \\
46406\end{array}$ & 11.5 \\
\hline $\begin{array}{l}\text { Collection agency account } \\
\text { Inquiry }\end{array}$ & $\begin{array}{r}46,496 \\
138,584\end{array}$ & $\begin{array}{l}17.5 \\
55.9\end{array}$ \\
\hline
\end{tabular}

1 Active accounts are those used within one year of the date the sample was drawn.

2. Individuals who are authorized to use an account but not legally responsible for its payment. Generally, these accounts will not be used in a credit evaluation of the authorized user.

3. Includes only inquiries made within two years of the date the sample was drawn.

* Less than 0.5 percent.

Individuals have credit reporting company records for a number of reasons: having a record of a credit account (whether open and active or not), being an authorized user on a credit account, having a money-related public record, having a record of a collection action, or having had an inquiry about their credit circumstances. Approximately 87 percent of individuals in the sample had a record of a credit account, and 92 percent of these had an open and active account as of the date the sample was drawn (table 1). A very small share of the individuals in the sample had only a public record item or an inquiry. However, about 11 percent of the sample had a credit reporting company record only because of a collection action.

The following discussion highlights the contents and scope of the data in the sample. A close examination of the data reveals that the information is not complete in all regards and at times contains duplications and ambiguities. These omissions and limitations may require users of the information to make assumptions about how to treat certain reported items in developing a credit profile for a consumer. The following discussion reviews the more important of these issues and quantifies their scope. Because the information is now somewhat dated, some of the patterns presented here may not reflect current circumstances. 
2. All credit accounts and balances, grouped by status and distributed by account characteristic Percent except as noted

\begin{tabular}{|c|c|c|c|c|c|c|c|c|c|}
\hline \multirow{4}{*}{ Account characteristic } & \multirow{4}{*}{$\begin{array}{c}\text { All accounts: } \\
\text { share } \\
\text { having } \\
\text { characteristic }\end{array}$} & \multicolumn{8}{|c|}{ Accidunt slistus } \\
\hline & & \multicolumn{4}{|c|}{ Currently repurtitd } & \multicolumn{4}{|c|}{ Not current y repiorlied } \\
\hline & & \multicolumn{2}{|c|}{ Open } & \multicolumn{2}{|c|}{ Clk sed } & \multicolumn{2}{|c|}{$\begin{array}{c}\text { Dos mant } \\
\text { (zero balance) }\end{array}$} & \multicolumn{2}{|c|}{$\begin{array}{c}\text { Unk nowin } \\
\text { (posit ve } 1 \text { ' } \\
\text { unknown balinuse) }\end{array}$} \\
\hline & & $\begin{array}{c}\text { Share } \\
\text { having } \\
\text { characteristic }\end{array}$ & $\begin{array}{c}\text { Share } \\
\text { of } \\
\text { characteristic }\end{array}$ & $\begin{array}{c}\text { Share } \\
\text { having } \\
\text { characteristic }\end{array}$ & $\begin{array}{c}\text { Share } \\
\text { of } \\
\text { characteristic }\end{array}$ & $\begin{array}{c}\text { Share } \\
\text { having } \\
\text { characteristic }\end{array}$ & $\begin{array}{c}\text { Share } \\
\text { of } \\
\text { characteristic }\end{array}$ & $\begin{array}{c}\text { Share } \\
\text { having } \\
\text { characteristic }\end{array}$ & $\begin{array}{c}\text { Share } \\
\text { of } \\
\text { characteristic }\end{array}$ \\
\hline \multicolumn{10}{|l|}{ Type of credit } \\
\hline Revolving .... & 62.7 & 71.2 & 36.1 & 44.3 & 29.9 & 95.4 & 27.6 & 51.5 & 6.4 \\
\hline Check credit & 1.8 & 1.9 & 35.2 & 1.3 & 30.9 & 2.6 & 27.3 & 1.5 & 6.7 \\
\hline Banking institution & 30.5 & 38.0 & 39.6 & 29.1 & 40.2 & 25.1 & 14.9 & 20.8 & 5.3 \\
\hline $\begin{array}{l}\text { Finance company } \\
\text { or credit union }\end{array}$ & 47 & 44 & 293 & 31 & 275 & 06 & 367 & 30 & 64 \\
\hline Retailer & 23.8 & $\begin{array}{r}4.4 \\
24.8\end{array}$ & $\begin{array}{l}29.3 \\
33.2\end{array}$ & $\begin{array}{r}3.1 \\
10.1\end{array}$ & $\begin{array}{l}27.5 \\
17.9\end{array}$ & $\begin{array}{r}9.6 \\
53.8\end{array}$ & $\begin{array}{l}36.7 \\
41.1\end{array}$ & $\begin{array}{r}3.9 \\
23.7\end{array}$ & $\begin{array}{l}6.4 \\
7.7\end{array}$ \\
\hline Other $^{1} \ldots$ & $\begin{array}{r}25.0 \\
1.9\end{array}$ & $\begin{array}{r}2+.0 \\
2.1\end{array}$ & 28.5 & 1.9 & 34.4 & $\begin{array}{r}75.0 \\
1.8\end{array}$ & 13.8 & 7.0 & 23.3 \\
\hline Nonrevolving & 4.7 & 4.1 & 27.9 & 4.0 & 36.4 & 4.6 & 18.0 & 10.7 & 17.8 \\
\hline Installment & 26.6 & 19.0 & 22.7 & 43.7 & 69.6 & .0 & .0 & 26.3 & 7.7 \\
\hline Mortgage . & 6.1 & 5.7 & 29.9 & 7.9 & 55.4 & .0 & 0 & 11.5 & 14.7 \\
\hline All accounts & 100.0 & 100.0 & 31.8 & 100.0 & 42.3 & 100.0 & 18.2 & 100.0 & 7.8 \\
\hline \multicolumn{10}{|l|}{ Мемо } \\
\hline $\begin{array}{l}\text { Percent of revolving accounts } \\
\text { missing credit limit }\end{array}$ & 34.9 & 32.3 & 49.3 & .0 & .0 & 39.2 & 45.8 & 28.6 & 4.8 \\
\hline \multicolumn{10}{|l|}{ Holder } \\
\hline Single & 78.9 & 80.0 & 32.3 & 74.8 & 40.2 & 85.3 & 19.6 & 81.0 & 8.0 \\
\hline Joint .. & 21.1 & 20.0 & 30.1 & 25.2 & 50.4 & 14.7 & 12.6 & 19.0 & 7.0 \\
\hline \multicolumn{10}{|l|}{ Creditor } \\
\hline Banking institution $\ldots \ldots \ldots$ & 44.7 & 48.2 & 34.3 & 51.4 & 48.6 & 27.2 & 11.0 & 35.3 & 6.1 \\
\hline Finance company or credit union & 19.8 & 14.9 & 24.0 & 26.9 & 57.7 & 10.2 & 9.4 & 22.9 & 9.0 \\
\hline Retailer $\ldots \ldots \ldots \ldots$ & 24.8 & 25.0 & 32.1 & 12.1 & 20.7 & 54.1 & 39.7 & 24.2 & 7.6 \\
\hline Other $^{1} \quad \ldots . . . . . . . . . .$. & 10.7 & 11.9 & 35.1 & 9.6 & 37.8 & 8.6 & 14.4 & 17.6 & 12.7 \\
\hline \multicolumn{10}{|l|}{ Date opened } \\
\hline Less than 1 year & 8.1 & 19.6 & 77.0 & 1.9 & 10.0 & 3.2 & 7.2 & 6.1 & 5.8 \\
\hline 1 to 2 years $\ldots$. & 9.3 & 16.0 & 54.7 & 5.5 & 24.8 & 5.8 & 11.3 & 11.0 & 9.2 \\
\hline 2 to 4 years ..... & 19.3 & 21.9 & 36.2 & 18.3 & 40.2 & 14.7 & 13.9 & 24.2 & 9.7 \\
\hline More than 4 years & 63.4 & 42.5 & 21.3 & 74.3 & 49.7 & 76.3 & 21.9 & 58.7 & 7.2 \\
\hline \multicolumn{10}{|l|}{ Date last had balance } \\
\hline Current...$\ldots \ldots \ldots$ & 31.0 & 67.1 & 68.7 & 4.6 & 6.3 & .0 & .0 & 1000 & 250 \\
\hline Less than 1 year & 13.8 & 17.3 & 39.8 & 13.6 & 41.6 & 14.2 & 18.6 & 0 & 0 \\
\hline 1 to 2 years $\ldots$. & 10.4 & 6.1 & 18.7 & 14.9 & 60.8 & 11.7 & 20.5 & 0 & 0 \\
\hline 2 to 4 years ..... & 16.7 & 5.9 & 11.2 & 24.8 & 63.1 & 23.6 & 25.7 & 0 & 0 \\
\hline More than 4 years & 28.1 & 3.6 & 4.1 & 42.0 & 63.3 & 50.5 & 32.6 & 0 & 0 \\
\hline \multicolumn{10}{|l|}{ Date last reported } \\
\hline Less than 2 months & 39.8 & 1000 & 800 & 18.8 & 20.0 & .0 & 0 & 0 & .0 \\
\hline 2 months to 1 year & 15.5 & 0 & 0 & 14.8 & 40.3 & 25.9 & 30.3 & 59.1 & 29.5 \\
\hline 1 to 2 years ...... & 8.9 & 0 & 0 & 12.9 & 61.5 & 12.1 & 24.7 & 15.9 & 13.8 \\
\hline 2 to 4 years .... & 13.8 & 0 & 0 & 20.6 & 62.9 & 22.4 & 29.4 & 13.7 & 7.7 \\
\hline More than 4 years & 22.0 & 0 & 0 & 32.9 & 63.3 & 39.7 & 32.7 & 11.3 & 4.0 \\
\hline \multicolumn{10}{|l|}{ Payment status ${ }^{2}$} \\
\hline Worst recorded & & & & & & & & & \\
\hline Major derogatory & 7.8 & 3.1 & 12.8 & 9.2 & 50.0 & 1.4 & 3.2 & 34.1 & 34.0 \\
\hline Minor derogatory & 7.0 & 8.0 & 36.7 & 6.5 & 39.2 & 4.9 & 12.7 & 10.2 & 11.4 \\
\hline No derogatory & 85.3 & 88.8 & 33.1 & 84.4 & 41.9 & 93.8 & 20.0 & 55.6 & 5.1 \\
\hline $\begin{array}{l}\text { At most-recent report } \\
\text { Balance remaining/ } \\
\text { balance unknown }\end{array}$ & & & & & & & & & \\
\hline Major derogatory & 4.3 & 2.1 & 15.1 & 2.7 & 26.3 & .0 & .0 & 32.5 & 58.5 \\
\hline Minor derogatory & 1.0 & 1.6 & 50.7 & .3 & 12.9 & .0 & .0 & 4.8 & 36.4 \\
\hline No derogatory & 25.7 & 63.5 & 78.4 & 1.6 & 2.7 & $*$ & $*$ & 62.7 & 18.9 \\
\hline No balance & 68.9 & 32.8 & 15.1 & 95.4 & 58.5 & 100.0 & 26.3 & 0 & .0 \\
\hline MEMO $^{3}$ & & & & & & & & & \\
\hline Number of accounts (millions) & 1,428 & 454 & & 604 & & 259 & $\cdots$ & 111 & \\
\hline Percent of dollars $\quad . . . \ldots \ldots .$. & 100.0 & $\ldots$ & 71.8 & $\ldots$ & 1.2 & $\cdots$ & .0 & $\ldots$ & 27.0 \\
\hline
\end{tabular}

Note. Here and in subsequent tables, data are a statistically representative sample of a national credit reporting company's credit record data as of June 30 , 1999; items may not sum to 100 because of rounding.

1. Includes national oil and gas companies, travel and entertainment companies, utility companies, real estate firms, government entities, and smaller retailers.

2. A minor derogatory status is a payment delinquency of 30 days to 119 days. A major derogatory status is a delinquency of 120 days or more, a

payment plan, repossession, charge-off, collection action, bankruptcy, foreclosure, or adverse judgment by a court

3. National estimates based on the sample. Not applicable

* Less than 0.05 percent.

SOURCE. Here and in subsequent tables, author calculations using statistically representative sample provided to the Federal Reserve Board by one of the three national credit reporting companies. 


\section{Personal Identifying Information}

All credit reporting company files include personal identifying information that allows the companies to distinguish among individuals and construct a full record of each consumer's credit-related activities. Files always include the consumer's name (and known aliases), current and previous addresses, and social security number. Other identifying information sometimes found in credit files includes date of birth, telephone number(s), spouse's name, number of dependents, income, and employment information. ${ }^{13}$ These data are most often supplied by creditors; they are taken from credit application files. Information about an individual's lifestyle (for example, sexual orientation) or personal characteristics (for example, race or national origin) are excluded from credit reporting company files.

One of the challenges that credit reporting companies face is constructing a unified credit record for a consumer. This challenge arises for a number of reasons. An individual's social security number, for example, may be recorded incorrectly on a loan application, or it may be transmitted incorrectly to the credit reporting companies. Problems also arise because the identifying information may not be current or because a consumer may have accounts under different names or addresses. For instance, a consumer may be inconsistent in using a full name in all applications for credit or may change names, perhaps after a marriage or divorce. Furthermore, accounts may be difficult to link to a given consumer if the consumer's address has changed. Credit reporting companies have established a series of protocols to address each of these challenges.

\section{Credit Account Information}

Credit accounts constitute the bulk of the information in the typical individual's credit record, and thus the information on credit accounts represents the majority of the information maintained by credit reporting companies. Credit account records contain many details about each account (see box "Credit Account Records").

\section{Account Status}

A basic element of credit reporting company data is information on the status of each account with

13. For further details, see "Consumer Information" on the web site of the Consumer Data Industry Association, www.cdiaoline.org. respect to whether the credit relationship is ongoing (an "open account") or whether the account is closed and cannot be added to by the consumer. Determining whether an account is open or closed is not always straightforward, in part because some creditors do not report all account closures to the credit reporting companies. Instead, in many situations, creditors simply stop reporting any information about an account, creating uncertainty about the current status of the account. These "not currently reported" accounts constitute a significant portion of all accounts in the credit reporting company data.

For the discussion that follows, credit accounts are grouped according to their status and whether or not they are currently reported. An account is currently reported if either (1) its status had been reported to the credit reporting company within two months of the date that the sample of credit records was drawn or (2) it was last reported (at any time) to be closed and had a zero balance at the date of last report. All installment and mortgage accounts paid down to a zero balance are treated as currently reported and closed. With these definitions, accounts fall into one of four mutually exclusive groups, two of which are currently reported and two not currently reported.

- Open credit accounts are currently reported and are not reported as closed. These include accounts that a consumer can use to incur additional debt, such as an open-end revolving account, and closed-end accounts that the consumer is paying down on a scheduled basis, such as a mortgage or an installment loan.

- Closed credit accounts are currently reported (as defined here) and are reported as closed. Closed accounts cannot be used to incur additional debt. Virtually all these accounts have been fully repaid and have a zero balance, although a positive balance remains on a small number of closed revolving accounts.

- Dormant accounts are non-installment, nonmortgage accounts that were last reported as open with no outstanding balance but for which the last reporting was more than two months before the sample was drawn. These accounts are inactive, but from the data, one cannot determine whether they are open or closed.

- An unknown accounts category contains all other accounts that are not currently reported. All these accounts were reported as having a balance at their last reporting date. The category includes installment, mortgage, and to a smaller extent, revolving accounts 


\section{Credit Account Records}

Credit account records include information on each "trade line" or credit account in a consumer's credit files. They include the following:

Account Dates

- The date the account was opened

- The date the account was closed (if applicable)

- The date the account was paid down to zero if the last reported balance is zero

- The account verification date (the date on which information on the account was taken)

- The date the account information was recorded by the credit reporting company.

\section{Account Balances}

- Account balance on the verification date (if any)

- The historic high balance (For mortgage or installment loans, this is generally the original balance.)

- Credit limit (the maximum amount that can be borrowed for revolving or open accounts)

- Amount past due (If the account is delinquent, this is the amount that was overdue as of the verification date.).

\section{Payment Performance}

- Payment status at the last report. This can have seven values:

1. unknown or too new to rate

2. satisfactory or paying as agreed

3. 30 to 59 days past the due date (minor derogatory)

4. 60 to 89 days past the due date (minor derogatory)

5. 90 to 119 days past the due date (minor derogatory)

6. 120 or more days past the due date (major derogatory)

7. other major derogatory instances (repossession, charge off, collection, judgment, bankruptcy, foreclosure, paying under a wage earner plan).

- Payment status pattern for the previous 48 months (not given for a major derogatory)

- Dispute code (indicates ifitems in the account are under dispute)

- Remark codes (for example, notations for types of payment problems and reasons for closing accounts).

\section{Account Description}

- Account ownership (individual, joint, authorized user, co-signer)

- Type of creditor (commercial bank, savings institution, finance company, credit union, government entity, retailer, and so forth).

- Type of account

- Closed end - a lump-sum loan that the borrower repays over time according to an agreed-upon schedule

- Mortgage - a special type of installment account that is secured by a primary residence or other residential real estate such as a rental or vacation property $^{1}$

- Installment-nonmortgage accounts, such as auto loans, that typically involve fixed monthly payments that fully amortize the total amount borrowed over the term of the loan, often secured.

-Open end-consumers can borrow from time to time at their discretion, typically up to some pre-authorized limit

- Revolving-typically unsecured accounts that permit considerable flexibility in the amount that must be paid back in any given billing cycle, typically a month, such as a credit card account

- Nonrevolving charge the account holder may borrow funds for a short period (typically a month) and must repay in full at the end of this period

- Check credit-a special form of revolving account, typically not accessible by a credit card, that includes personal lines of credit and overdraft protection on deposit-related accounts, such as a checking account.

- Loan purpose or type (for example, credit card 3 charge account, automobile loan, student loan, or FHA-insured mortgage)

- Lender subscriber code.

1. An exception is the home equity line of credit, which, though secured by real property, is typically structured more like a line of credit or revolving account. Some home equity lines of credit are reported as mortgages; others are often reported as open-end revolving accounts. that may have been paid off but lack a final record of disposition. It also includes accounts that were sold or transferred to another creditor or collection department or agency but not reported as closed by the selling or transferring institutions. Finally, it includes accounts that have encountered such severe payment problems that the creditor no longer reports the account.
The status was currently reported for about 74 percent of the accounts in the sample. ${ }^{14}$ Of these accounts, 57 pereent were closed; the remainder were open. Because these accounts were currently

14. The data used for this study represent the complete credit records of a nationally representative sample of individuals. However, raw account distributions in such data are not proper estimates of 
reported, users of the data did not have to make assumptions about their current status.

The status of the remaining credit accounts was not currently reported, and thus assumptions had to be made in order to use the data. Among the accounts that were not currently reported, 70 percent were dormant. For these accounts, the only issue a user of the data had to address was whether the account could be used by a consumer. The accounts in the unknown category, which comprised about 8 percent of all the credit accounts in the sample, present a particularly vexing problem for users of the data because this category includes accounts that had a positive or unknown balance at the date of last report. This category includes accounts that may have been sold, transferred, or paid offi but are not reported as such. Also included are accounts, particularly derogatory accounts, that are still outstanding but on which the lender has ceased reporting.

\section{Types of Accounts}

Credit reporting companies ask creditors to place each credit account into one of four broad groupings: two types of open-end account (revolving and nonrevolving) and two types of closed-end account (installment and mortgage). Within these four categories, further distinctions can be made by users of the data based on other characteristics - for example, the reported purpose of the loan or the type of creditor.

Revolving accounts were by far the most common type of credit account found in the sample, comprising about 63 percent of all credit accounts and about 71 percent of all open accounts (table 2). Although revolving accounts made up the largest share of accounts, approximately 28 percent of these accounts were dormant. Installment accounts composed the second largest share of credit accounts, representing approximately 27 percent of all accounts in the credit reporting company files. Much less frequently found in these files are records of nonrevolving charge accounts and mortgages. Given the relatively short terms to maturity of most installment loans, it is not surprising to find that installment accounts composed a disproportionate share of all closed accounts in the sample of credit records.

the distribution of characteristics of a representative sample of credit accounts. This disparity occurs because many accounts, including joint accounts or accounts with co-signers, are contained in the credit records of multiple individuals. An adjustment for such multiple reporting was made in computing the statistics reported in this article to make them representative of all credit accounts.

\section{Types of Creditors}

Credit reporting company data include the identities and a type classification of the credit provider for each account. For purposes of this analysis, the creditor type classification was used to group accounts into four categories: banking institutions (commercial banks and savings associations), finance companies and credit unions, retailers, and "other." The retail category includes department stores and jewelry, computer, camera, and sporting goods stores. "Other" includes national oil and gas companies, travel and entertainment companies, other retailers, and various creditors such as utility companies, real estate firms, and government entities.

Banking institutions were the largest source of credit accounts recorded in the credit reporting company files, accounting for nearly 45 percent of all the credit accounts and 48 percent of open accounts. The second largest source of credit accounts was retailers. The distribution of accounts by creditor type varies some by account status and is largely a function of the types of accounts that creditors offer. For example, finance companies and credit unions offer primarily installment accounts, which are more likely than revolving accounts to have been paid down and closed. Banking institutions and retailers offer relatively large numbers of revolving accounts, which tend to be used from time to time and to retain their open status.

\section{Date Account Opened and}

\section{Last Had Balance}

Most credit accounts were several years old when the sample was drawn; only 8 percent of the credit accounts recorded in the files were less than one year old, and nearly two-thirds had been opened at least four years previously. Among accounts that were known to be open, about 20 percent had been open less than one year, and nearly 58 percent had been open four years or less. Not surprisingly, a large proportion of dormant and closed accounts were at least four years old.

Only about one-third of accounts currently had a balance when the sample was drawn. However, twothirds of the open accounts showed a balance. Overall, 28 percent of accounts had not had a balance within four years of the time the sample was drawn. More than 50 percent of the dormant accounts had not had a balance within four years. 


\section{Payment Status and Balances Owed}

The credit account records include information on the extent of consumer payment problems and the amount owed on an account. Nearly 70 percent of all accounts and 33 percent of accounts currently reported as open showed no outstanding balance at the time of most recent reporting. Among accounts with balances, more than one-fourth of the balance dollars at last date of reporting were associated with accounts in the "unknown" category (table 2, last row). The large share of outstanding balances that fell in the unknown category highlights the importance of decisions about how to treat accounts in this category when using the data for credit evaluations or other purposes.

With respect to payment performance, accounts were sorted into one of three categories: accounts with no "derogatory" (no record of late payment), those with evidence of a "minor derogatory" (a late payment of 30-59, 60-89, or 90-119 days), and those with evidence of a "major derogatory." Credit accounts categorized as major derogatory include any account that is delinquent 120 days or more and all credit accounts reported as associated with bankruptcy, foreclosure, repossession, civil judgment, collection, charge-off, and so forth. ${ }^{15}$

The analysis presents two ways of describing payment history. First, accounts are sorted by their worst recorded payment problem. Second, accounts are sorted by their payment status at the time the credit reporting company last received information on the account (their "status at most-recent report"). As discussed below, both worst payment problem and status at most-recent report are weighed heavily by creditors when conducting credit evaluations.

Worst payment problem. More than 85 percent of all accounts had no record of a payment problem. The remaining accounts were split about evenly between those with, at worst, a minor derogatory and those with a major derogatory. Patterns differ sharply between open and closed accounts. Only about 3 percent of open accounts had a major derogatory status, whereas 9 percent of closed accounts had this status. This difference results from the general industry practice of closing accounts that experience severe payment problems. More than one-third of the accounts that had a major derogatory were not cur-

15. Regulatory guidance for banking institutions requires that closed-end loans, such as installment loans, must be charged off after 120 days of delinquency. Open-end loans are required to be charged off after being delinquent 180 days or more. See Federal Reserve Board Supervisory Letter SR 99-5, February 18, 1999. rently reported and were last reported with a positive or unknown balance.

Status at most-recent report. About 5 percent of all accounts were reported as having payment problems at the time of the most-recent reporting; most of the accounts with payment problems were reported as having a major derogatory. The incidence of accounts exhibiting a major derogatory at last report differs from that of accounts that ever exhibited a major derogatory because more than half the accounts with a historic major derogatory had been closed and showed a zero balance.

\section{Interpreting the Credit Account Data}

As the preceding discussion highlights, credit reporting company data provide a wide-ranging and comprehensive picture of accounts that reflects individuals' experiences with credit. However, the discussion also reveals that, in some instances, the data are not sufficiently up-to-date or complete to permit a clear understanding of an account's current status. The following sections present a more detailed look at the information in the credit reporting company files, focusing on items most pertinent to credit evaluation. ${ }^{16}$

Credit evaluators rely on a number of factors in assessing the credit quality of individuals. The exact weight attached to specific factors varies across evaluators and their different models, but the factors generally fall in three broad areas: the level of a consumer's indebtedness, the payment history, and credit account characteristics. ${ }^{17}$

\section{Level of Consumer Indebtedness}

When evaluating credit, creditors consider the type and amount of debt a consumer has and the proportion of available credit he or she has in use (credit utilization). For revolving accounts, credit utilization is measured as the proportion of available credit in use (outstanding balance divided by credit limit). For mortgage and installment accounts, credit utilization is generally measured as the proportion of the origi-

16. Credit evaluation is the most prominent use of the data, and the original motivation for its collection, but other uses of the data exist and may emphasize different items.

17. For a more detailed discussion of factors considered in credit evaluation, including the relative weights given to different factors, see the description on the web site of Fair Isaac and Company, www.myfico.com. Also see Avery et al., "Credit Risk, Credit Scoring, and the Performance of Home Mortgages." 
nal loan amount that is unpaid, referred to here as the paydown rate.

Fundamental to measuring consumer indebtedness is deciding which accounts to treat as active-that is, installment and mortgage accounts with positive balances and revolving accounts upon which consumers can draw. Clearly, credit evaluators would include currently reported open accounts as active in any calculations. The difficulty, however, is in determining how to treat accounts that are in the dormant and unknown categories. The dormant category likely includes many accounts that are not currently reported but can be further drawn upon by the consumer. For example, some creditors do not provide updates for accounts that have a zero balance and no recent activity. The unknown category also likely includes some accounts that are still active.

For the present analysis of consumer indebtedness, the definition of "active" includes currently reported open accounts as well as dormant revolving accounts that were last reported within the year before the date the sample was drawn. Discussions with industry professionals, however, indicate that there is no strict rule regarding a single appropriate choice of time period cutoff. The choice of the cutoff affects the number of accounts deemed to be active and the potential borrowing capacity of an individual but has no bearing on the amounts owed because all the dormant accounts had zero balances at the time of last report. For reasons discussed below, this study includes no accounts from the unknown category, which are believed most likely to be closed.

Outstanding balances. Most consumer indebtedness on active accounts involves mortgages. Mortgages represented about 67 percent of the dollars outstanding but only 5 percent of the active credit accounts (table 3 ). Nearly 30 percent of all active mortgages in the data had outstanding balances of $\$ 100,000$ or more. Installment accounts, accounting for about 22 percent of the balances, involved the second largest proportion of all consumer debt. Installment accounts also tended to be relatively large; 46 percent had balances of $\$ 5,000$ or more. In contrast, revolving accounts represented a relatively small share of outstanding balances (11 percent), even though they were by far the largest proportion of active accounts measured by number. This difference arises because

3. Open accounts and balances, by type of account

Percent except as noted

\begin{tabular}{|c|c|c|c|c|c|c|c|c|c|c|c|c|c|c|}
\hline \multirow{2}{*}{ Type of account } & \multicolumn{2}{|c|}{ Accs unts } & \multicolumn{8}{|c|}{ Distribution of balances, by dollar size of balance } & \multicolumn{2}{|c|}{$\begin{array}{l}\text { Dolla: size } \\
\text { of bal:minect } \\
\text { accoun.s will } \\
\text { a balince }\end{array}$} & \multicolumn{2}{|c|}{$\begin{array}{l}\text { Dollar-v cigltited } \\
\text { bala acess }\end{array}$} \\
\hline & $\begin{array}{l}\text { Share } \\
\text { of } \\
\text { account } \\
\text { type }\end{array}$ & $\begin{array}{c}\text { Share } \\
\text { of all } \\
\text { open } \\
\text { accounts }\end{array}$ & 0 & $\begin{array}{l}1- \\
249\end{array}$ & $\begin{array}{r}250- \\
499\end{array}$ & $\begin{array}{l}500- \\
999\end{array}$ & $\begin{array}{l}1,000- \\
4,999\end{array}$ & $\begin{array}{l}5,000- \\
9,999\end{array}$ & $\begin{array}{l}10,000- \\
99,999\end{array}$ & $\begin{array}{c}100,000 \\
\text { or } \\
\text { more }\end{array}$ & Mean & Median & $\begin{array}{c}\text { Share } \\
\text { of } \\
\text { account } \\
\text { type }\end{array}$ & $\begin{array}{c}\text { Share } \\
\text { of all } \\
\text { open } \\
\text { accounts }\end{array}$ \\
\hline Revolving ...... & 100.0 & 74.3 & 53.0 & 14.6 & 7.1 & 6.8 & 13.5 & 3.7 & 1.2 & * & 2,015 & 595 & 100.0 & 11.3 \\
\hline Check credit $\ldots$. & 2.5 & 1.9 & 51.2 & 5.4 & 4.9 & 5.3 & 14.3 & 6.2 & 12.3 & .3 & 9.736 & 2,934 & 12.8 & 1.4 \\
\hline Banking institution & 49.9 & 37.0 & 40.6 & 13.4 & 7.6 & 8.4 & 21.6 & 6.7 & 1.7 & $*$ & 2,370 & 1,022 & 74.2 & 8.4 \\
\hline 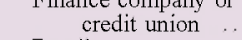 & 6.3 & 4.7 & 39.8 & 17.6 & 8.9 & 10.3 & 18.7 & 3.0 & 1.6 & $*$ & 1,887 & 645 & 7.6 & 9 \\
\hline Retailer ............. & 37.9 & 28.1 & 70.5 & 16.8 & 6.3 & 4.0 & 2.3 & .1 & .0 & .0 & 378 & 201 & 4.5 & .5 \\
\hline Other $^{2}$ & 3.4 & 2.5 & 66.0 & 9.8 & 6.9 & 7.6 & 9.5 & .2 & $*$ & .0 & 847 & 513 & 1.0 & .1 \\
\hline Nonrevolving & 100.0 & 4.2 & 48.4 & 34.3 & 5.2 & 4.1 & 5.2 & 1.3 & 1.4 & $*$ & 1,227 & 107 & 100.0 & 4 \\
\hline Installment & 100.0 & 16.5 & .4 & 3.7 & 4.0 & 7.5 & 38.1 & 20.1 & 25.8 & .3 & 8,256 & 4,354 & 100.0 & 21.8 \\
\hline Banking institution & 30.5 & 5.1 & 1 & 1.5 & 2.2 & 4.6 & 32.2 & 24.7 & 34.1 & .7 & 11,077 & 6,697 & 41.1 & 8.9 \\
\hline Auto credit ...... & 11.3 & 1.9 & $*$ & .8 & 1.3 & 2.4 & 22.4 & 30.7 & 42.4 & .1 & 10,005 & 8.743 & 13.8 & 3.0 \\
\hline $\begin{array}{l}\text { Finance company or } \\
\text { credit union }\end{array}$ & 22.6 & 3.7 & .1 & 1.9 & 2.4 & 4.2 & 25.3 & 24.7 & 41.3 & .2 & 10,366 & 8,225 & 28.5 & 6.2 \\
\hline Auto credit ...... & 16.4 & 2.7 & $*$ & 1.1 & 1.2 & 2.1 & 19.8 & 27.3 & 48.6 & $*$ & 10,973 & 9,745 & 21.9 & 4.8 \\
\hline Retailer and other ${ }^{2}$. & 46.9 & 7.8 & .8 & 6.0 & 6.0 & 11.0 & 48.2 & 14.8 & 13.0 & .2 & 5,384 & 2,620 & 30.5 & 6.6 \\
\hline Mortgages & 100.0 & 5.0 & * & .2 & .1 & .2 & 2.2 & 3.2 & 64.2 & 29.9 & 83,699 & 68,000 & 100.0 & 66.5 \\
\hline All open accounts & 100.0 & 100.0 & 41.5 & 12.9 & 6.1 & 6.5 & 16.7 & 6.3 & 8.4 & 1.6 & 10,678 & 1,483 & 100.0 & 100.0 \\
\hline $\begin{array}{l}\text { Мемо } \\
\text { Closed accounts with } \\
\text { positive balances }\end{array}$ & & & & & & & & & & & & & & \\
\hline Currently reported $\ldots$. & 100.0 & & .0 & 20.2 & 16.5 & 18.3 & 34.3 & 8.4 & 2.3 & $*$ & 2,010 & 822 & 100.0 & \\
\hline Not currently reported & 100.0 & & .0 & 20.0 & 10.3 & 12.4 & 31.1 & 9.4 & 14.1 & 2.8 & 11,357 & 1,455 & 100.0 & \\
\hline
\end{tabular}

Note. Excludes accounts in a major derogatory status (for definition, see table 2 , note 2 ).

1. Excludes accounts in dispute.

2. "Other" includes national oil and gas companies, travel and entertainment companies, utility companies, real estate firms, government entities, and smaller retailers.

. Not applicable

* Less than 0.05 percent. 
4. Borrowing capacity on open accounts

Percent except as noted

A. Credit limits reported

\begin{tabular}{|c|c|c|c|c|c|c|c|c|c|}
\hline \multirow{2}{*}{ Type of account } & \multirow{2}{*}{$\begin{array}{c}\text { Share of } \\
\text { account type } \\
\text { having } \\
\text { credit } \\
\text { limit } \\
\text { reported }\end{array}$} & \multirow{2}{*}{$\begin{array}{l}\text { Mean } \\
\text { credit } \\
\text { limit } \\
\text { (dollars) }\end{array}$} & \multirow{2}{*}{$\begin{array}{l}\text { Median } \\
\text { credit } \\
\text { limit } \\
\text { (dollars) }\end{array}$} & \multicolumn{6}{|c|}{ 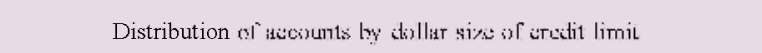 } \\
\hline & & & & $\begin{array}{c}1- \\
499\end{array}$ & $\begin{array}{c}500- \\
999\end{array}$ & $\begin{array}{l}1,000- \\
4,999\end{array}$ & $\begin{array}{l}5,000- \\
9,999\end{array}$ & $\begin{array}{l}10,000- \\
24,999\end{array}$ & $\begin{array}{l}25,000 \\
\text { or more }\end{array}$ \\
\hline Revolving ..... & 67.5 & 4,534 & 2,500 & 8.5 & 16.3 & 40.5 & 22.4 & 11.0 & 1.3 \\
\hline Check credit ..... & 84.3 & 12,002 & 3,500 & 6.1 & 12.2 & 35.6 & 15.5 & 15.5 & 15.1 \\
\hline Banking institution & 60.1 & 7,036 & 6,000 & 3.1 & 5.4 & 27.8 & 39.5 & 22.4 & 1.8 \\
\hline $\begin{array}{c}\text { Finance company or } \\
\text { credit union }\end{array}$ & 88.4 & 3,467 & 2,500 & 4.5 & 10.5 & 60.9 & 19.2 & 4.4 & .5 \\
\hline 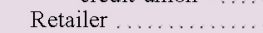 & 71.9 & 1,575 & 1,000 & 15.9 & 30.3 & 47.8 & 5.6 & .4 & $*$ \\
\hline Other $^{1}$ & 74.5 & 2,808 & 2,500 & 3.2 & 11.3 & 71.6 & 13.0 & 1.0 & $*$ \\
\hline Installment & 99.5 & 11,152 & 7,060 & 2.6 & 4.3 & 33.9 & 18.5 & 32.6 & 8.3 \\
\hline Mortgages & 99.6 & 92,797 & 75,400 & $*$ & $*$ & 3 & 9 & 7.7 & 91.1 \\
\hline
\end{tabular}

more than half of all revolving accounts had zero balances and many accounts had relatively small credit limits, effectively restricting the amounts a consumer could borrow. Among the types of revolving accounts, those issued by retailers are the most likely to show a zero balance.

The large share of revolving accounts that showed a zero balance at last report is not surprising. The use of credit cards varies greatly because some cards are unused for a period of time whereas others are used regularly either as a convenient means of payment or a source of credit. Whether a card is reported as having a balance is not an indicator of whether the card is being used to borrow for an extended period or is being used simply as a convenient payment device. Even when a consumer pays the full balance billed each month on a card used regularly, the credit report is likely to show a balance due. Such a balance appears because payments are not received and credited immediately and additional charges are likely to be made between the date the last bill was generated and the date that balance information is sent to the credit reporting company.

Credit limits. To calculate a utilization rate for a revolving account, one must have information on both an account's outstanding balance and its credit limit. The credit limit, however, is not regularly reported for all accounts. Approximately one-third of all active revolving accounts in the sample lacked such information (table 4A). ${ }^{18}$ For these accounts, other techniques are required to estimate a utilization

18. The incidence of missing credit limits is significantly lower in credit reporting company data at present. According to industry estimates, credit limits are currently missing on about 13 percent of revolving accounts. The higher incidence of missing limits in the sample may stem from a period when a few large creditors decided to suspend reporting of this item for competitive reasons. Pressure from financial institution regulators and the credit reporting companies appears to have convinced these creditors to resume reporting credit limits. See Robert M. Hunt, "The Development and Regulation of rate. The most common approach in these circumstances is to use the highest balance ever reported on the account (either the current balance or the historic high balance) as a surrogate for the credit limit. As described below, this alternative approach creates very different profiles regarding the extent to which revolving accounts have been drawn on. For mortgages and installment loans, the credit limit and the high balance (the original amount borrowed) are the same, and so the profiles will be identical.

Credit limits on revolving accounts are not typically very large. About 25 percent of the sample accounts meeting the authors' definition of active had limits under $\$ 1,000$, and about 41 percent had credit limits in the $\$ 1,000$ to $\$ 4,999$ range (table 4A). Only a very small proportion of revolving accounts had limits of $\$ 25,000$ or more. ${ }^{19}$ By contrast, mortgages and, to a lesser degree, installment loans had much higher credit limits (original balances). More than 90 percent of the mortgage accounts had original balances over $\$ 25,000$, and 41 percent of installment loans had original balances of $\$ 10,000$ or more.

Using data from the sample, one can also profile the distribution of credit limits across different types of creditors. For example, the average credit limit for revolving accounts from all sources was approximately $\$ 4,500$. Credit limits for revolving accounts tended to be highest at banking institutions, at about $\$ 7,000$, and lowest among retailers, at about $\$ 1,600$.

Consumer Credit Reporting in America," Federal Reserve Bank of Philadelphia, Working Paper no. 02-21, November 2002.

19. The data also indicate that within the broad revolving account category used here, check credit accounts have, on average, much higher credit limits than other types of revolving accounts. The average credit limit for active check credit accounts reporting a limit was about $\$ 12,000$ compared with an average of $\$ 4,500$ for all types of revolving accounts. The relatively high credit limits for check credit accounts may reflect the inclusion of some home-secured loans in that category. So-called home equity lines of credit typically involve relatively high credit limits because their credit risk is mitigated by the security offered by the account holder. 


\section{4.-Continued}

Percent except as noted

B. Credit limits not reported (highest balance used as a proxy)

\begin{tabular}{|c|c|c|c|c|c|c|c|c|c|c|c|}
\hline \multirow[b]{2}{*}{ Type of account } & \multirow{2}{*}{$\begin{array}{l}\text { Share of } \\
\text { account } \\
\text { type } \\
\text { not } \\
\text { having } \\
\text { credit } \\
\text { limit } \\
\text { reported }\end{array}$} & \multirow[b]{2}{*}{$\begin{array}{l}\text { Mean } \\
\text { highest } \\
\text { balance } \\
\text { (dollars) }\end{array}$} & \multirow[b]{2}{*}{$\begin{array}{l}\text { Median } \\
\text { highest } \\
\text { balance } \\
\text { (dollars) }\end{array}$} & \multicolumn{6}{|c|}{ Distrilution of accounts by dollar size of highest balance } & \multicolumn{2}{|c|}{ Memo } \\
\hline & & & & $\begin{array}{c}1- \\
499\end{array}$ & $\begin{array}{l}500- \\
999\end{array}$ & $\begin{array}{l}1,000- \\
4,999\end{array}$ & $\begin{array}{l}5,000- \\
9,999\end{array}$ & $\begin{array}{c}10,000- \\
24,999\end{array}$ & $\begin{array}{l}25,000 \\
\text { or more }\end{array}$ & $\begin{array}{l}\text { Historic } \\
\text { high } \\
\text { balance } \\
\text { not } \\
\text { reported }\end{array}$ & $\begin{array}{c}\text { Hi storic } \\
\text { high } \\
\text { balance } \\
\text { reported }\end{array}$ \\
\hline Revolving ..... & 32.5 & 1,351 & 353 & 43.8 & 19.2 & 27.9 & 6.9 & 1.8 & .4 & 24.7 & 75.3 \\
\hline Check credit ..... & 15.7 & 9,887 & 2,471 & 6.2 & 11.7 & 37.1 & 16.6 & 14.0 & 14.4 & 17.8 & 82.2 \\
\hline Banking institution & 39.9 & 1,605 & 374 & 30.7 & 16.3 & 38.5 & 11.7 & 2.5 & .3 & 33.7 & 66.3 \\
\hline $\begin{array}{c}\text { Finance company or } \\
\text { credit union }\end{array}$ & 11.6 & & & 146 & & 51.1 & & & & 9.6 & 90.4 \\
\hline Retailer............ & 28.1 & 484 & 310 & 64.7 & $\begin{array}{l}13.8 \\
22.8\end{array}$ & $\begin{array}{l}51.1 \\
12.3\end{array}$ & $\begin{array}{r}11.4 \\
.2\end{array}$ & $\begin{array}{l}1.9 \\
*\end{array}$ & $\begin{array}{r}1.0 \\
.0\end{array}$ & $\begin{array}{r}9.0 \\
10.0\end{array}$ & 90.0 \\
\hline Other $^{1} \ldots \ldots \ldots$ & 25.5 & 522 & 400 & 52.0 & 32.7 & 15.2 & 2 & .0 & .0 & 16.9 & 83.1 \\
\hline
\end{tabular}

NoTE. Excludes accounts in a major derogatory status (for definition, see table 2 , note 2 ) or in dispute.

* Less than 0.05 percent

Differences in credit limits across types of institutions likely reflect a combination of factors, including differences in the creditworthiness of customers, customer demand for credit, and the types of transactions for which the account can be used. For example, a furniture store may offer higher credit limits on its revolving accounts than a retailer carrying only apparel and accessories.

The profile of credit limits differs notably between accounts that had credit limits reported and those that used the highest-balance proxy. For revolving accounts, the latter had a much larger percentage of accounts with limits under $\$ 1,000$ than did the former (compare the revolving account category in tables $4 \mathrm{~A}$ and 4B). Thus, the use of the highest-balance measure for credit limits on accounts in which limits are not reported likely understates the actual credit limits available on those accounts.

Utililization rates. Combining information on outstanding balances and credit limits (or highest balances for revolving accounts if the credit limit was not reported) allows users of the data to calculate account utilization rates. As before, notable differences exist between accounts with credit limits reported and those using the highest-balance proxy (table 5). These differences stem both from the use of

Evidence from the Federal Reserve's 2001 Survey of Consumer Finances shows that households with a line of credit have an average income of approximately $\$ 111,000$. In comparison, those with a revolving account have an average income of about $\$ 82,000$. For further information about the survey, see Ana M. Aizcorbe, Arthur B. Kennickell, and Kevin B. Moore, "Recent Changes in U.S. Family Finances: Evidence from the 1998 and 2001 Survey of Consumer Finances," Federal Reserve Bulletin, vol. 89 (January 2003), pp. 1-32. For information on home equity lines of credit see Glenn B. Canner, Thomas A. Durkin, and Charles A. Luckett, "Recent Developments in Home Equity Lending," Federal Reserve Bulletin, vol. 84 (April 1998), pp. 241-51.
1. Includes national oil and gas companies, travel and entertainment companies, utility companies, real estate firms, government entities, and smaller retailers.

a different measure of credit limit and from correlations between the propensity of a creditor to report a credit limit and the account characteristics. For example, observed differences in the share of accounts that had utilization rates of zero can be caused only by differences in the propensity to report credit limits. ${ }^{20}$ However, differences in the proportion of active revolving accounts calculated to have either relatively low utilization rates (from 1 percent to 24 percent) or very high rates ( 95 percent or more) can be strongly influenced by which measure of credit limit is used. Here, some observed differences are substantial. For revolving accounts with reported credit limits, 20 percent had a utilization rate in the low range, whereas 5 percent of accounts using the highest-balance proxy fell in this range. At the other extreme, only 6 percent of active revolving accounts with reported credit limits had a utilization rate of 95 percent or more, whereas 31 percent of revolving accounts that used the highest-balance proxy had utilization rates this high.

Differences in calculated utilization rates also are clearly revealed in estimates of the mean and median utilization rates using the two different measures of credit limit. Not surprisingly, mean and median utilization rates were substantially lower for revolving accounts with a reported credit limit than they were for accounts using the highest-balance proxy.

20. For the construction of tables 3, 4, and 5, the authors assumed that dormant accounts last reported within one year of when the sample was drawn were still open to the consumer and could be used for borrowing. The authors also reviewed the ways in which the patterns shown in these tables changed when a two-year rule was used. As might be expected, the main effect was to increase the proportion of revolving accounts showing a zero utilization; however, the effect is small-increasing the share by only a couple of percentage points. 
5. Use of borrowing capacity on open accounts Percent

\begin{tabular}{|c|c|c|c|c|c|c|c|c|}
\hline \multirow[t]{2}{*}{ Type of account } & \multicolumn{6}{|c|}{ Distribution of accounts, by percent of credit limit or highest-balance proxy used } & \multicolumn{2}{|c|}{$\begin{array}{l}\text { Meno: } \\
\text { Share of cr zlit limit ir } \\
\text { highest-balance proxy used, } \\
\text { accounts wi.l a bilames }\end{array}$} \\
\hline & 0 & $1-24$ & $25-49$ & $50-74$ & $75-94$ & 95 or more & Mean & Median \\
\hline & \multicolumn{8}{|c|}{ Credit lim ts reported } \\
\hline Revolving ....... & 55.1 & 20.0 & 6.8 & 5.8 & 6.6 & 5.8 & 19.6 & .0 \\
\hline Check credit ..... & 51.2 & 9.4 & 7.4 & 8.9 & 12.8 & 10.2 & 30.6 & .0 \\
\hline Banking institution & 41.1 & 26.5 & 7.9 & 7.0 & 9.1 & 8.4 & 26.0 & 2.3 \\
\hline $\begin{array}{l}\text { Finance company or } \\
\text { credit union } \ldots\end{array}$ & 38.2 & 26.7 & 9.8 & 8.6 & 9.3 & 7.5 & 27.3 & 5.3 \\
\hline Retailer $\ldots \ldots \ldots \ldots$ & 73.4 & 12.7 & 4.9 & 3.7 & 2.9 & 2.4 & 10.5 & .0 \\
\hline Other $^{1}$ & 64.9 & 15.4 & 7.4 & 5.1 & 4.0 & 3.2 & 14.4 & .0 \\
\hline Installment & 4 & 8.5 & 13.0 & 20.8 & 25.2 & 32.1 & 72.7 & 81.7 \\
\hline \multirow[t]{2}{*}{ Mortgage } & $*$ & 2.9 & 4.7 & 11.7 & 31.6 & 49.1 & 86.2 & 94.7 \\
\hline & \multicolumn{8}{|c|}{ Credit limits not repurted (highest-lalance proxy used) } \\
\hline Revolving ..... & 48.7 & 5.3 & 4.2 & 4.8 & 5.7 & 31.2 & 41.3 & 5.5 \\
\hline Check credit ...... & 51.3 & 6.4 & 6.2 & 8.6 & 12.2 & 15.4 & 34.3 & .0 \\
\hline Banking institution & 40.0 & 2.2 & 1.9 & 3.5 & 5.8 & 46.7 & 54.8 & 85.4 \\
\hline Finance company or & & & & & & & & \\
\hline $\begin{array}{l}\text { credit union } \cdots \\
\text { Retailer }\end{array}$ & 52.8 & 6.3 & $\begin{array}{l}6.5 \\
83 \\
8\end{array}$ & $\begin{array}{l}8.2 \\
69\end{array}$ & 12.1 & 14.1 & 32.9 & .0 \\
\hline Other ${ }^{1}$.. & 69.2 & 4.7 & 5.3 & 5.8 & 4.9 & 10.1 & 20.3 & .0 \\
\hline
\end{tabular}

Patterns of missing credit limits. The discussion above highlights the different implied utilization profiles of accounts with and without credit limits reported. To detect systematic patterns in the reporting of credit limits, a linking index variable (discussed in footnote 2) was used to examine the relationship between the creditor and the likelihood that a credit limit was missing. Results suggested that most of the variation in the reporting of credit limits for active revolving accounts can be explained by the identity of the creditor. Restricted to creditors that reported a large number of accounts, the analysis divided these creditors into three groups: those that reported credit limits for fewer than 5 percent of their accounts; those that reported credit limits for more than 95 percent of accounts; and all others. ${ }^{21}$ In the first group were only 12 percent of the creditors in the analysis, but they accounted for 74 percent of the total accounts with missing credit limits and less than 0.03 percent of those with limits reported. At the other extreme, the second group, representing 68 percent of the creditors and 86 percent of the accounts for which limits were reported, accounted for less than 1 percent of the accounts with missing limits.

21. For this analysis the authors used a threshold of seventy-five active revolving accounts reported in the sample to define a "large" creditor. This criterion was met by 674 creditors. These creditors accounted for 96 percent of all missing credit limits in the credit reporting company files
The group in the middle, representing 20 percent of the creditors, is also interesting. These creditors reported limits for some active revolving accounts but not for others. Concerns have been raised that some creditors report limits selectively-in particular, that they do not report limits for some subprime customers because they do not want these customers to be targeted for solicitation by other creditors. The analysis finds only mild support for this view. Overall, 51 percent of the active revolving accounts of subprime customers held at creditors in this middle group had their credit limit reported versus 53 percent of accounts of their prime customers. ${ }^{22}$ However, for a subset of creditors in this middle groupabout 5 percent of the creditors in the analysis-all specializing (more than 50 percent of their accounts) in subprime lending, some degree of selective reporting did appear to take place. For prime customers of these creditors, credit limits were reported about 77 percent of the time versus 40 percent for subprime customers at these institutions.

\section{Payment History}

Perhaps the most important factors considered in credit evaluation are a consumer's history of repay-

22. The authors used an internally developed credit score supplied by the credit reporting company with the credit files to make a rough determination of prime and subprime borrowers. 
6. All credit accounts and recently opened accounts, by worst payment status recorded Percent

\begin{tabular}{|c|c|c|c|c|c|c|c|c|c|c|c|c|c|c|}
\hline \multirow{3}{*}{ Type of account } & \multicolumn{7}{|c|}{ All accounts } & \multicolumn{7}{|c|}{ Recently spensed iecosunts } \\
\hline & \multirow{2}{*}{$\begin{array}{c}\text { No } \\
\text { deroga- } \\
\text { tory }\end{array}$} & \multicolumn{3}{|c|}{$\begin{array}{l}\text { Min «r dirrogatory } \\
\text { (day; delinquent) }\end{array}$} & \multicolumn{2}{|c|}{ Vilijor ditroratory } & \multirow[b]{2}{*}{ Total } & \multirow{2}{*}{$\begin{array}{c}\text { No } \\
\text { deroga- } \\
\text { tory }\end{array}$} & \multicolumn{3}{|c|}{$\begin{array}{l}\text { Minor deringitisy } \\
\text { (days telinquent) }\end{array}$} & \multicolumn{2}{|c|}{ Major deringitisty } & \multirow[b]{2}{*}{ Total } \\
\hline & & $30-59$ & $60-89$ & $90-119$ & $\mid \begin{array}{c}120-149 \\
\text { days } \\
\text { delin- } \\
\text { quent }\end{array}$ & Other & & & $30-59$ & $60-89$ & $90-119$ & $\mid \begin{array}{c}120-149 \\
\text { days } \\
\text { delin- } \\
\text { quent }\end{array}$ & Other & \\
\hline Revolving ...... & 85.6 & 4.6 & 1.8 & .8 & 1.2 & 6.0 & 100.0 & 92.5 & 3.1 & 1.2 & .6 & .7 & 1.9 & 100.0 \\
\hline Check credit .......... & 90.0 & 3.5 & $\begin{array}{l}1.0 \\
1.1\end{array}$ & .6 & .7 & 4.2 & 100.0 & 94.9 & 2.5 & .6 & .4 & .3 & 1.4 & 100.0 \\
\hline Banking institution & 86.1 & 4.3 & 1.7 & .7 & 1.0 & 6.3 & 100.0 & 91.9 & 3.3 & 1.4 & .6 & .8 & 2.1 & 100.0 \\
\hline $\begin{array}{l}\text { Finance company or } \\
\text { credit union } \ldots\end{array}$ & 86.5 & 5.5 & 1.8 & 9 & 1.4 & 3.9 & 100.0 & 94.0 & 3.0 & 9 & 4 & 6 & 1.0 & 100.0 \\
\hline Retailer ............. & 84.7 & 5.0 & 2.0 & 1.0 & 1.4 & 5.9 & 100.0 & 92.8 & 3.0 & 1.0 & .6 & .7 & 1.8 & 100.0 \\
\hline Other $^{1}$ & 83.4 & 4.6 & 1.7 & .9 & 1.4 & 8.0 & 100.0 & 94.0 & 2.7 & .8 & 4 & .5 & 1.7 & 100.0 \\
\hline Nonrevolving & 72.6 & 2.2 & 1.5 & 1.1 & 2.9 & 19.7 & 100.0 & 64.1 & 2.5 & 1.7 & 1.3 & 2.5 & 27.9 & 100.0 \\
\hline Installment $\ldots \ldots \ldots$ & 85.3 & 4.3 & 1.6 & 1.0 & 1.7 & 6.1 & 100.0 & 90.1 & 3.4 & 1.1 & .7 & .9 & 3.8 & 100.0 \\
\hline Banking institution & 90.3 & 4.0 & 1.4 & 6 & 7 & 3.0 & 100.0 & 94.0 & 3.0 & .9 & .3 & .3 & 1.5 & 100.0 \\
\hline $\begin{array}{c}\text { Finance company or } \\
\text { credit union }\end{array}$ & 87.4 & 6.1 & 1.4 & 4 & .6 & 4.2 & 100.0 & 93.9 & 3.5 & .8 & .2 & .3 & 1.2 & 100.0 \\
\hline Retailer and other ${ }^{1}$ & 79.7 & 3.5 & 1.8 & 1.7 & 3.3 & 9.9 & 100.0 & 85.3 & 3.6 & 1.5 & 1.1 & 1.7 & 6.9 & 100.0 \\
\hline Mortgages & 91.0 & 4.3 & 1.4 & 7 & 8 & 1.9 & 100.0 & 96.2 & 2.3 & .5 & .2 & .2 & .6 & 100.0 \\
\hline All accounts & 85.3 & 4.4 & 1.7 & .9 & 1.4 & 6.4 & 100.0 & 90.9 & 3.1 & 1.1 & .6 & .8 & 3.4 & 100.0 \\
\hline
\end{tabular}

1. "Other" includes national oil and gas companies, travel and entertainment companies, utility companies, real estate firms, government entities, and smaller retailers.

ing loans and any evidence of money-related public actions or non-credit-related collections. Credit evaluators consider whether a consumer has a history of repaying balances on credit accounts in a timely fashion. Such an analysis considers not only the frequency of any repayment problems but also their severity (how late), recency, and dollar magnitude. Repayment performance is evaluated on the full range of accounts that a consumer holds, spanning accounts that vary by type of account and type of creditor. This section profiles the credit reporting company data on payment history on credit accounts; later sections present data on public records and collection actions on non-credit-related bills.

In assessing the credit circumstances of an individual, creditors often look at both the consumer's recent payment experience on credit accounts and his or her record of payments over a much longer period. ${ }^{2.3}$ In general, an individual with a major derogatory will find qualifying for new credit difficult, may face high interest rates for the credit received, or may be limited in further borrowing on existing open accounts. In addition, creditors typically close an account that is associated with a major

23. As noted, the Fair Credit Reporting Act specifies that consumer credit reports cannot include any adverse item of information that is more than seven years old unless it involves a bankruptcy (which has a ten-year limit), criminal conviction (no time limit), or one of a few other narrow exceptions (see box "A Summary of Consumer Rights under the Fair Credit Reporting Act"s). derogatory, effectively preventing the consumer from adding new debt to that account. The payment performance profiles obtained from the data are influenced both by consumers' behavior regarding their accounts and by the reporting practices of creditors.

Worst payment status recorded Credit payment history can be evaluated by focusing on the worst derogatory status recorded for an account, that is, on the most severe problem in an account. About 85 percent of revolving accounts and of installment accounts showed no record of a delinquent payment or of a major derogatory (table 6). Mortgages showed fewer problems, with 91 percent of these accounts showing no evidence of payment problems. This large proportion may reflect the high priority that consumers place on meeting payment obligations secured by their homes. Nonrevolving accounts were most likely to have experienced a major derogatory; however, the high incidence of major derogatories among nonrevolving accounts may be due not to poorer consumer performance but rather to the nonreporting of accounts with no major problems.

Among all installment accounts, a little more than half of those evidencing a payment problem involved a major derogatory. In contrast, only about 30 percent of mortgages with a payment problem involved a major derogatory, while nearly all payment problems among nonrevolving accounts involved a major derogatory. 
7. All credit accounts, distributed by payment status at most-recent report Percent

\begin{tabular}{|c|c|c|c|c|c|c|c|c|c|}
\hline \multirow{2}{*}{ Type of account } & \multicolumn{3}{|c|}{$\begin{array}{l}\text { No terogatiory } \\
\text { (account status) }\end{array}$} & \multicolumn{3}{|c|}{$\begin{array}{l}\text { Minar derogatioy } \\
\text { (diyys dislinculueni) }\end{array}$} & \multicolumn{2}{|c|}{ Major derogatory } & \multirow[b]{2}{*}{ Total } \\
\hline & $\begin{array}{c}\text { Closed, } \\
\text { no } \\
\text { balance }\end{array}$ & $\begin{array}{c}\text { Open, } \\
\text { no } \\
\text { balance }\end{array}$ & $\begin{array}{l}\text { Open, } \\
\text { positive } \\
\text { balance }\end{array}$ & $30-59$ & $60-89$ & $90-119$ & $\begin{array}{c}120-149 \\
\text { days } \\
\text { delinquent }\end{array}$ & Other & \\
\hline Revolving ...... & 47.7 & 22.9 & 24.8 & .5 & .3 & .2 & 4 & 3.2 & 100.0 \\
\hline Check credit ........ & 52.8 & 20.1 & 23.6 & .3 & .2 & .2 & 3 & 2.4 & 100.0 \\
\hline Banking institution .. & 46.9 & 18.0 & 30.4 & .5 & .3 & .2 & 4 & 3.3 & 100.0 \\
\hline Finance company or & & & & 5 & 3 & 2 & 5 & 24 & 1000 \\
\hline Retailer ............ & $\begin{array}{l}56.4 \\
47.2\end{array}$ & $\begin{array}{l}14.5 \\
30.5\end{array}$ & $\begin{array}{l}25.3 \\
17.9\end{array}$ & .3 & $\begin{array}{l}.3 \\
.2\end{array}$ & .2 & $\begin{array}{l}5 \\
4\end{array}$ & $\begin{array}{l}2.4 \\
3.3\end{array}$ & $\begin{array}{l}100.0 \\
1000\end{array}$ \\
\hline Other ${ }^{1} \ldots \ldots \ldots$ & 41.9 & 31.7 & 20.2 & .6 & .2 & .2 & .6 & 4.6 & 100.0 \\
\hline Nonrevolving & 43.8 & 16.0 & 22.5 & .5 & .4 & .4 & 1.8 & 14.6 & 100.0 \\
\hline Installment $\ldots \ldots \ldots$ & 69.6 & .1 & 24.7 & .6 & .3 & .2 & 6 & 3.9 & 100.0 \\
\hline Banking institution & 74.9 & $*$ & 22.4 & .5 & .2 & 1 & 2 & 1.7 & 100.0 \\
\hline Finance company or & & & & & & & & & \\
\hline credit union $\ldots$ & 70.6 & $*$ & 25.6 & .7 & .2 & .1 & .2 & 2.7 & 100.0 \\
\hline Retailer and other ${ }^{1}$.. & 64.5 & .2 & 26.3 & .6 & 4 & 4 & 1.1 & 6.6 & 100.0 \\
\hline Mortgages & 55.4 & $*$ & 42.6 & .8 & .3 & .1 & 4 & .5 & 100.0 \\
\hline All accounts & 53.8 & 15.1 & 25.7 & .5 & .3 & .2 & .5 & 3.8 & 100.0 \\
\hline
\end{tabular}
ment companies, utility companies, real estate firms, government entities, and smaller retailers

About 91 percent of recently opened accounts showed no record of delinquent payments or of a major derogatory. Such performance might be expected, in part because payment problems take time to emerge as consumers encounter adverse changes in their employment or personal circumstances (for example, health problems or marital difficulties). Although the incidence of any problem is lower for recently opened accounts than for others, the likelihood that a minor delinquency deteriorates into a major derogatory is about the same as for all accounts. Among the recently opened accounts, mortgages again evidenced the fewest problems, with 96 percent of these accounts showing no payment problems.

Payment status at most-recent report. This section details the distribution of all accounts according to their most-recent reported payment performance when the sample was drawn. This measure is the last status for the account reported by the creditor. Thus, for accounts not currently reported, this status may have changed but not have been reported by the time the sample was drawn.

The proportion of accounts experiencing current payment problems is much lower than the proportion of accounts ever having a payment problem (compare table 7 with table 6). This difference arises because many accounts experiencing payment problems "cure"- that is, regain nonderogatory payment status (most of these end up as closed accounts with zero balances). Account curing is particularly preva- lent among accounts with minor delinquencies, reflecting the fact that minor delinquency is a transitory state; the accounts either cure or deteriorate into a major derogatory. For example, only 0.5 percent of all accounts at the most-recent report were 30-59 days past due whereas more than 4 percent had a worst payment status of 30-59 days past due.

When evaluating credit payment history, creditors consider the length of time since a currently nonderogatory account was last delinquent. Recent payment problems on an account generally weigh more heavily than problems further in the past. This concept is most relevant for active accounts. Among accounts that were active when the sample was drawn, 91 percent had never been delinquent (table 8). Among active accounts that had been delinquent at some time but were not delinquent at last report, a little more than half were delinquent during the twelve-month period preceding the drawing of the sample.

\section{Current Status}

The data presented in tables 3 through 8 reflect the status of accounts at the date of most-recent reporting. A credit evaluator, however, is likely to be interested in the current status of accounts - that is, the status at the time the credit evaluation is made. For currently reported accounts or for accounts that are closed or dormant, the account status at the date of last reporting will be the correct current status in 
8. Nonderogatory credit accounts, distributed by the length of time since last delinquency recorded Percent

\begin{tabular}{|c|c|c|c|c|c|c|c|c|c|c|c|c|}
\hline \multirow[b]{2}{*}{ Type of account } & \multicolumn{6}{|c|}{ 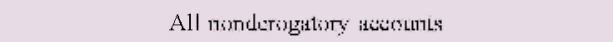 } & \multicolumn{6}{|c|}{ Actise nimdersing } \\
\hline & Never & Unknown & $\begin{array}{c}1-12 \\
\text { months }\end{array}$ & $\begin{array}{l}13-24 \\
\text { months }\end{array}$ & $\begin{array}{c}\text { More } \\
\text { than } \\
24 \\
\text { months }\end{array}$ & Total & Never & Unknown & $\begin{array}{c}1-12 \\
\text { months }\end{array}$ & $\begin{array}{l}13-24 \\
\text { months }\end{array}$ & $\begin{array}{c}\text { More } \\
\text { than } \\
24 \\
\text { months }\end{array}$ & Total \\
\hline Revolving ..... & 89.8 & 3.3 & 2.7 & 1.5 & 2.8 & 100.0 & 91.1 & .5 & 4.6 & 2.0 & 1.8 & 100.0 \\
\hline Check credit ..... & 93.2 & 2.4 & 1.6 & .9 & $\begin{array}{l}2.0 \\
1.9\end{array}$ & 100.0 & 94.4 & .3 & 2.9 & 1.3 & 1.1 & 100.0 \\
\hline Banking institution & 90.4 & $\begin{array}{l}2.4 \\
3.6\end{array}$ & $\begin{array}{l}1.0 \\
2.7\end{array}$ & 1.3 & 2.0 & 100.0 & 91.9 & .4 & 4.5 & $\begin{array}{l}1.3 \\
1.7\end{array}$ & $\begin{array}{l}1.1 \\
1.5\end{array}$ & 100.0 \\
\hline $\begin{array}{l}\text { Finance company or } \\
\text { credit union }\end{array}$ & 89.9 & 2.8 & 2.3 & 1.5 & 3.5 & 1000 & 903 & 10 & 48 & 20 & 20 & 1000 \\
\hline 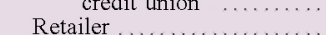 & $\begin{array}{l}89.9 \\
88.7\end{array}$ & $\begin{array}{l}2.8 \\
2.9\end{array}$ & $\begin{array}{l}2.3 \\
2.8\end{array}$ & $\begin{array}{l}1.5 \\
1.7\end{array}$ & $\begin{array}{l}3.5 \\
3.8\end{array}$ & $\begin{array}{l}100.0 \\
1000\end{array}$ & $\begin{array}{l}90.3 \\
89.8\end{array}$ & 1.0 & $\begin{array}{l}4.8 \\
4.9\end{array}$ & $\begin{array}{l}2.0 \\
2.4\end{array}$ & $\begin{array}{l}2.0 \\
2.3\end{array}$ & 100.0 \\
\hline Other ${ }^{1} \ldots \ldots \ldots$ & 88.9 & 3.9 & 2.9 & 1.7 & 2.6 & 100.0 & 91.4 & .5 & 4.1 & 2.2 & 1.7 & 100.0 \\
\hline Nonrevolving $\ldots$ & 88.3 & 7.7 & 1.7 & 1.0 & 1.4 & 100.0 & 93.5 & 1.0 & 3.2 & 1.2 & 1.1 & 100.0 \\
\hline Installment ......... & 90.3 & 5.2 & 1.5 & .8 & 2.1 & 100.0 & 91.8 & 1.1 & 4.6 & 1.6 & 1.0 & 100.0 \\
\hline Banking institution & 92.9 & 3.9 & 1.2 & .6 & 1.5 & 100.0 & 93.4 & .7 & 3.9 & 1.3 & .7 & 100.0 \\
\hline $\begin{array}{c}\text { Finance company or } \\
\text { credit union }\end{array}$ & 90.9 & 3.4 & 1.7 & 1.0 & 3.0 & 100.0 & 92.3 & .3 & 5.1 & 1.5 & .8 & 100.0 \\
\hline Retailer and other ${ }^{1} \ldots \ldots \ldots$ & 87.6 & 7.5 & 1.7 & 1.0 & $\begin{array}{l}3.0 \\
2.2\end{array}$ & 100.0 & 90.3 & 1.8 & $\begin{array}{l}3.1 \\
4.8\end{array}$ & $\begin{array}{l}1.3 \\
1.8\end{array}$ & 1.8 & 100.0 \\
\hline Mortgages & 92.8 & 2.7 & 1.6 & .9 & 2.0 & 100.0 & 93.2 & .4 & 3.2 & 1.4 & 1.8 & 100.0 \\
\hline All nonderogatory accounts .. & 90.1 & 3.9 & 2.3 & 1.3 & 2.5 & 100.0 & 91.4 & .6 & 4.5 & 1.8 & 1.7 & 100.0 \\
\hline
\end{tabular}

1. "Other" includes national oil and gas companies, travel and entertainment companies, utility companies, real estate firms, government entities, and smaller retailers.

virtually all cases. One exception occurs because of inconsistencies in the way creditors report account delinquencies. About 11 percent of active accounts were reported by creditors that did not report minor delinquencies for any accounts. An additional 12 percent were reported by creditors that did not report delinquencies of 30-59 days. Nonrevolving accounts were particularly likely to fall in these categories. No evidence indicates that these creditors do not update their accounts at the same rate as other creditors; instead, they appear to be reporting accounts as nondelinquent until the accounts reach a seriously delinquent status. Consequently, customers of these creditors tend to show a lower incidence of minor delinquencies than do the customers of other creditors.

For accounts in the "unknown" category, a much more serious question is whether or not the account status at the date of last reporting is the same as the account's correct current status. For this category, the creditor has not updated the account information for at least three months (and often much longer), and the account shows a positive balance, raising the likelihood that the status has changed since it was last reported. There is reason to believe that major derogatory accounts in the unknown category differ from others in their likelihood of a changed status; thus, they are discussed separately.

Unknown category accounts not in major derogatory status. The current status of nonderogatory and minor derogatory accounts in the unknown category is likely to differ in most circumstances from that last reported. Since these accounts showed positive balances at the date of last reporting (signifying that they were open), one can infer that their status had changed by the time the sample was drawn: Either the account was closed or transferred or the account holder made payments, and thus changed his or her balance, or did not make payments, in which case the performance status worsened. The most notable exception is for records of some types of student loans where repayment may be deferred for a period of time. About 67 percent of all accounts in the unknown category were not in major derogatory status at the date of last reporting. About two-thirds of these accounts were revolving or open nonrevolving accounts. Most of these accounts require monthly payments, and thus it seems highly unlikely that their status at last report reflects their current circumstances.

Recognizing the high likelihood that many noncurrently reported accounts have had a change in status, the credit reporting companies have adopted "stale account" rules. The credit reporting company's rule in place at the time the sample was drawn was to define all revolving and nonrevolving accounts with positive balances and no major derogatories as stale if they had not been reported within six months. Stale accounts were treated as closed and were assigned a zero balance. The data reflect this rule. Sixty-one percent of the revolving and nonrevolving accounts in the unknown category had been reported within six months before the date the sample was drawn (and 
more than 80 percent within the year before). These accounts are likely candidates for the stale account rule, and the probability that they have been closed or transferred is significant. The remaining accounts, constituting about 3 percent of all nonclosed revolving and nonrevolving accounts, were exceptions to the stale account rule. The actual status of these accounts is less clear.

Stale account rules were not used for mortgage and installment accounts by the credit reporting company that supplied the data for this study. ${ }^{24}$ As a consequence, a significantly higher percentage of these accounts than of revolving and nonrevolving accounts are in the unknown category. Almost onethird (32.5 percent) of all nonderogatory and minor derogatory mortgages last reported with a positive balance were in the unknown category. Only 33 percent of these had been reported within six months of the date the sample was drawn. One can infer that many, if not most, of these accounts had been closed or transferred. Specifically, for more than one-half the mortgages in the unknown category, the credit records showed that a new mortgage for approximately the same amount reported was opened within two months of the last reporting of the mortgage in the unknown category - a strong indicator that the mortgage in the unknown category was refinanced or that the servicing was sold.

Installment loans show a similar but less striking pattern. About one-fifth of the nonclosed, nonderogatory and minor derogatory installment accounts are in the unknown category; 33 percent of these were last reported within six months of the date the sample was drawn. One can infer that many of the loans may not have been outstanding when the sample was drawn. About 48 percent of nonderogatory and minor derogatory installment accounts in the unknown category have one of two conditions - either they are beyond the original due date at the time the sample was drawn or the gap between the date the sample was drawn and the last date they were reported is larger than any previous gap in their payment history.

There is another indication that many of the nonderogatory or minor derogatory mortgage and installment accounts in the unknown category may not have been outstanding when the sample was drawn. More than one-half of the loans in the unknown category for each account type were reported by creditors that had not reported on any accounts in the sample within three months of the time the sample was

24. The credit reporting company that supplied the data has indicated that it is in the process of implementing stale account procedures for these types of accounts. drawn. ${ }^{25}$ If these creditors no longer reported to the credit reporting companies, these accounts could have been updated only by the consumer or by a credit reporting company action, such as applying a stale account rule.

The consequence of accounts that have not been accurately reported as closed or transferred will, in most cases, be that consumers will show higher aggregate account balances. The issue goes beyond the actual balances owed and includes uncertainty about the extent of any payment problems as well. As shown in table 2 , about 36 percent of all accounts that were last reported as minor delinquencies were in the unknown category. For four-fifths of the installment accounts and about two-thirds of the other accounts in the unknown category with minor delinquencies shown at the date of last report, the account had not been reported within six months of the date the sample was drawn. Thus, their status had likely changed, but because the information remained unchanged in the files, these accounts could disproportionately affect the assessment of current minor delinquency.

Unknown category accounts last reported in major derogatory status. Unlike nonderogatory and minor derogatory accounts, the status of a major derogatory account can remain unchanged for a long time. The consumer may have stopped paying, and the creditor may have stopped trying to collect on the account. Thus, an account's status could in fact remain the same and not require updating. The failure to update is reflected in the sample data. Fifty-nine percent of the accounts last reported as unpaid (positive balance) major derogatories were in the unknown category. Of these, more than one-quarter had not been updated for more than four years.

Limited evidence shows that some of these accounts were likely paid off but that the update was not reported to the credit reporting company. Specifically, for about 10 percent of the unknown category mortgages with major derogatories, another mortgage was reported as originated after the date the account had last been reported. Generally, creditors require that all major derogatories be paid off before a new mortgage is originated. Similarly, a mortgage was reported as originated after the date of last report for about 3 percent of other unknown category accounts with major derogatories.

Further evidence shows that even if some major derogatories in the unknown category had been paid

25. Creditors had to have reported at least ten sample accounts to be included in this calculation. 
off, the payoff may not have been reported. About 32 percent of the major derogatory accounts in the unknown category were reported by creditors that had not reported on any accounts within three months of the date the sample was drawn. If these creditors are no longer active reporters, then even paid-off accounts are unlikely to be recorded as such. The account may still have existed, but it may have been transferred or sold and thus reported twice. In these circumstances, if the consumer paid off the account, then only one of these duplicate records might be updated as paid. ${ }^{26}$

Further, almost 12 percent of the major derogatory accounts in the unknown category were reported by creditors that, in the sample, reported only derogatory accounts. Such reporting patterns are particularly prevalent with nonrevolving accounts, for which the figure is about 35 percent. These creditors may simply not report when accounts are paid off or the consumer starts making payments. Reporting only major derogatory accounts has another implication for the completeness of credit files. Satisfactorily performing accounts of the creditors that so report are not included in the files, and thus the extent of

26. To test this conjecture, the percentage of all accounts that had ever been reported as major derogatories and that were last reported satisfactory (paid off: or making payments) were compared for two groups of creditors: (1) those that had not reported any accounts within three months of the date the survey was drawn and (2) those that had reported. For each group, the examination was restricted to accounts that were opened in the same three-year period (1995 through 1997). Creditors that were currently reporting accounts had an incidence rate showing satisfactory performance that was about 50 percent higher than the rate that creditors not currently reporting had. these nonreported accounts is unknown. The failure to report accounts in good standing may affect the credit evaluation of consumers with such accounts. For example, if consumers have low utilization of these nonreported accounts, the failure to report may worsen their credit evaluation. For those consumers having nonreported accounts with high utilization, however, the failure to report may actually improve credit evaluation.

\section{Account Characteristics}

When conducting credit evaluations, creditors consider a range of account-related characteristics, including the types of credit accounts an individual has established, how long the individual has had a particular credit account, and the last time the credit account carried a balance. Evaluators also assess the extent to which consumers have made recent requests for new credit as measured by certain types of inquiries made to a credit reporting company.

One such characteristic, the age of the account, may be relevant to an evaluation of credit quality because, for example, the longer the account has been open, the more information it may convey through its payment history. New accounts may convey little information other than that the consumer had a very recent need for additional credit and was approved for credit. In this context, length of time since an account was opened is most pertinent with respect to active accounts and least pertinent for accounts that have long been closed. Among active revolving accounts, which represent three out of four active

9. All credit accounts, distributed by the number of years since the accounts were opened Percent

\begin{tabular}{|c|c|c|c|c|c|c|c|c|c|c|}
\hline \multirow[b]{2}{*}{ Type of account } & \multicolumn{5}{|c|}{ All accounts } & \multicolumn{5}{|c|}{ Active accoun $s$} \\
\hline & $\begin{array}{l}\text { One } \\
\text { or less }\end{array}$ & $1-2$ & $2-4$ & $\begin{array}{l}\text { More } \\
\text { than } 4\end{array}$ & Total & $\begin{array}{l}\text { One } \\
\text { or less }\end{array}$ & $1-2$ & $2-4$ & $\begin{array}{l}\text { More } \\
\text { than } 4\end{array}$ & Total \\
\hline Revolving ..... & 8.0 & 8.9 & 19.2 & 63.9 & 100.0 & 16.5 & 14.1 & 21.3 & 48.1 & 100.0 \\
\hline Check credit ..... & 5.7 & 7.1 & 16.5 & 70.6 & 100.0 & 13.1 & 12.6 & 21.6 & 52.7 & 100.0 \\
\hline Banking institution & 9.0 & 9.5 & 20.9 & 60.6 & 100.0 & 17.9 & 14.3 & 22.6 & 45.2 & 100.0 \\
\hline \multicolumn{11}{|l|}{ Finance company or } \\
\hline credit union $\ldots$ & 9.0 & 10.7 & 20.0 & 60.3 & 100.0 & 21.9 & 18.3 & 21.8 & 38.0 & 100.0 \\
\hline Retailer ............. & 6.5 & 7.9 & 16.4 & 69.2 & 100.0 & 13.5 & 13.1 & 18.5 & 54.9 & 100.0 \\
\hline Other ${ }^{1}$ & 11.4 & 10.1 & 26.4 & 52.1 & 100.0 & 21.7 & 15.5 & 30.7 & 32.2 & 100.0 \\
\hline Nonrevolving & 6.0 & 8.4 & 17.5 & 68.1 & 100.0 & 10.9 & 10.8 & 15.7 & 62.6 & 100.0 \\
\hline Installment ......... & 8.6 & 10.5 & 21.0 & 60.0 & 100.0 & 29.4 & 24.3 & 27.7 & 18.7 & 100.0 \\
\hline Banking institution & 7.3 & 9.3 & 19.2 & 64.2 & 100.0 & 30.5 & 25.8 & 29.0 & 14.7 & 100.0 \\
\hline \multicolumn{11}{|l|}{ Finance company or } \\
\hline & 9.1 & 10.8 & 21.8 & 58.3 & 100.0 & 32.9 & 30.0 & 28.6 & $\begin{array}{r}8.5 \\
26 ?\end{array}$ & 100.0 \\
\hline & & & & & & & & & & \\
\hline Mortgages ... & 7.8 & 9.1 & 13.7 & 69.4 & 100.0 & 21.5 & 18.8 & 17.7 & 42.0 & 100.0 \\
\hline All accounts & 8.1 & 9.3 & 19.3 & 63.4 & 100.0 & 18.6 & 15.9 & 21.9 & 43.6 & 100.0 \\
\hline
\end{tabular}

1. "Other" includes national oil and gas companies, travel and entertainment companies, utility companies, real estate firms, government entities, and smaller retailers. 
accounts, about 30 percent were two years old or less as of the date the sample was drawn, and 48 percent were more than four years old (table 9). Mortgage accounts tended to be somewhat younger than revolving accounts, with about 40 percent two years old or less and 42 percent more than four years old. Installment accounts were the youngest overall-about 54 percent of these accounts were two years old or less-and nonrevolving the oldest, with 63 percent more than four years old.

For closed and other accounts that were reported to have a zero balance as of their last date of report, the length of time since the account had a balance may be more pertinent, since to some degree this measure indicates the timeliness of information available from the account's payment history. Among accounts last reported to have a zero balance, revolving and nonrevolving accounts tended to be paid down to zero more recently than installment accounts and mortgages. For instance, 25 percent of revolving and nonrevolving accounts with a zero balance last had a positive balance within a year of the date the sample was drawn, compared with 11 percent of installment accounts and 16 percent of mortgages. About half of installment and mortgage accounts with a zero balance last had a positive balance no less than four years before the date the sample was drawn, compared with about one-third of revolving accounts.

\section{Public Records, Collections, and, Inquiries}

Besides credit account information, information derived from various public records, reports from collection agencies, and creditor inquiries about a consumer's credit history is included in credit reporting company records (see box "Non-Credit-Account Data Included in Credit Records"). Credit evaluators consider these types of information in assessing the credit quality of individuals. However, issues of missing or ambiguous information complicate the use of these data.

\section{Public records}

The types of public information available from government entities include records of bankruptcy filings, liens, judgments, and some foreclosures and lawsuits. The data regarding bankruptcy distinguish between the types of personal bankruptcies. The two main types of consumer bankruptcies are Chapter 7 and Chapter 13, each named after the chapter in the U.S. bankruptcy code that defines the nature of the

\section{Non-Credit-Account Data Included in Credit Records}

Public Records

Public records include information from public legal filings collected either directly by public institutions and provided to the credit reporting companies or recorded by third parties from public records. Public records include information on foreclosures, civil judgments, or tax liens reported for the consumer over the past seven years, and bankruptcies filed during the previous ten years. Information on each judgment, lien, or bankruptcy includes the following:

- Date of the public record

- Type of filing (tax lien, foreclosure, bankruptcy chapter)

- Current status (filed, dismissed, paid, granted)

- Amount of the claim (or assets and liabilities for bankruptcies)

- Court docket number

- Name ofithe plaintiff.

Collection Account Records

Collection account records consist of icredit accounts and records of unpaid bills, such as bills for utility services, that have been transferred to a collection agency or are otherwise in the process of collection. Collection account records include the following information:

- Date that the item was turned over to the collection agency

- Date that the account information was recorded by the credit reporting company

- Account status (paid or unpaid)

- Amount currently owed as of the verification date (not applicable for paid accounts)

- Collection agency's subscriber code

- Name of the original creditor.

Inquiry Records

Inquiry records consist of information about the consumer requested by a creditor. Inquiry records are maintained for two years and include the following:

- Date of the inquiry

- Type of credit being considered (missing for most inquiries)

- Inquiry requestor's subscriber code.

proceedings. Chapter 7 provides for liquidation bankruptcies, which involve the liquidation of all nonexempt assets and the discharge of almost all debts. Chapter 13 provides for so-called wage-earner plans that involve the full or partial repayment of debts 
10. Public records, distributed by dollar amount of claim

Percent

\begin{tabular}{|c|c|c|c|c|c|c|c|c|}
\hline \multirow{2}{*}{ Type of public record } & \multirow{2}{*}{$\begin{array}{l}\text { Memo: } \\
\text { Distribution by } \\
\text { record type }\end{array}$} & \multicolumn{7}{|c|}{ Distri.sutisis al' pulalic records, by ameunt of claim (dollars)' } \\
\hline & & 0 & $1-250$ & $251-500$ & $501-1,000$ & $1,001-5,000$ & $5,001-10,000$ & 10,001 or more \\
\hline Bankruptcy & 22.7 & $\ldots$ & $\ldots$ & $\ldots$ & $\ldots$ & $\ldots$ & $\ldots$ & $\ldots$ \\
\hline Chapter 7 . & 75.9 & $\ldots$ & $\ldots$ & $\ldots$ & $\ldots$ & $\ldots$ & $\ldots$ & $\ldots$ \\
\hline Chapter 13 & 23.7 & $\ldots$ & $\ldots$ & $\ldots$ & $\ldots$ & $\ldots$ & $\ldots$ & $\ldots$ \\
\hline Other $\ldots .$. & .3 & $\cdots$ & $\cdots$ & $\cdots$ & $\cdots$ & $\ldots$ & $\cdots$ & $\cdots$ \\
\hline Foreclosure & .9 & 19.1 & 1.5 & 0 & .3 & 4.2 & 1.8 & 73.2 \\
\hline Lien $\ldots \ldots \ldots \ldots . . . .$. & 34.1 & 32.2 & 9.1 & 7.2 & 9.7 & 21.6 & 8.0 & 12.2 \\
\hline Federal government & 28.3 & 20.0 & 8 & 1.4 & 2.8 & 22.6 & 18.0 & 34.4 \\
\hline State government. & 65.9 & 36.3 & 12.5 & 9.5 & 12.5 & 21.3 & 4.2 & 3.7 \\
\hline Local government. & 5.3 & 48.6 & 10.1 & 8.3 & 10.3 & 19.9 & 1.8 & 1.0 \\
\hline Other $^{2} \quad \ldots \ldots \ldots$ & .5 & 7.4 & 20.4 & 11.4 & 16.5 & 28.4 & 11.9 & 4.0 \\
\hline Judgment . & 39.7 & 15.8 & 12.2 & 13.6 & 17.1 & 32.3 & 5.9 & 3.1 \\
\hline Medical & 18.4 & 18.5 & 16.8 & 19.4 & 19.4 & 21.7 & 2.9 & 1.3 \\
\hline Utılity $\ldots \ldots \ldots$ & 3.1 & 17.6 & 17.9 & 16.4 & 22.3 & 22.4 & 2.2 & 1.2 \\
\hline Government .... & 5.1 & 15.1 & 19.2 & 13.7 & 14.2 & 26.6 & 7.0 & 4.2 \\
\hline Collection agency & 9.2 & 29.7 & 14.0 & 15.6 & 14.8 & 22.4 & 2.9 & .6 \\
\hline Creditor $^{2} \quad \ldots \ldots$. & 18.9 & 11.3 & 4.7 & 5.3 & 10.8 & 46.9 & 14.8 & 6.1 \\
\hline Other $^{3}$ & 45.4 & 13.8 & 12.0 & 14.0 & 19.3 & 33.8 & 2.9 & .6 \\
\hline Lawsuit ... & 2.6 & 24.3 & 9.8 & 9.5 & 13.5 & 28.4 & 9.0 & 5.4 \\
\hline Medical & 17.7 & 30.1 & 15.2 & 11.8 & 16.5 & 19.6 & 4.7 & 2.0 \\
\hline Ut 1 lity .... & 4.5 & 26.6 & 8.8 & 23.0 & 21.2 & 19.5 & .9 & .0 \\
\hline Government $\ldots$ & 3.9 & 40.6 & 10.4 & 5.2 & 15.6 & 17.7 & 4.2 & 6.3 \\
\hline Collection agency & 5.7 & 16.8 & 24.5 & 10.5 & 16.1 & 18.9 & 10.5 & 2.8 \\
\hline Creditor $^{2} \quad \ldots \ldots$. & 25.4 & 13.3 & 2.2 & 48 & 9.3 & 44.2 & 17.2 & 9.1 \\
\hline Other $^{3} \quad \ldots \ldots \ldots$ & 42.9 & 27.4 & 9.9 & 10.0 & 13.3 & 26.4 & 7.3 & 5.7 \\
\hline All public records ${ }^{4}$ & 76.4 & 23.4 & 10.7 & 10.6 & 13.7 & 27.4 & 7.0 & 7.2 \\
\hline
\end{tabular}

1. Public records with reported amounts equal to zero have been paid or dismissed. The original amounts involved in the public action are not included in the records

2. Includes large retailers, banking institutions, and finance companies.

3. Includes small retailers, law firms, in
4. Excludes bankruptcy and foreclosure. - Not applicable. while assets are shielded from creditor action. ${ }^{27}$ The data also distinguish (albeit imperfectly) between federal, state, and local tax liens and other liens. Otherwise, unlike credit account data, the public record data do not provide a classification code for the type of creditor or plaintiff (for example, a provider of medical services or a utility company). However, by examining the names of plaintiffs, one can distinguish among broad types of judgments and lawsuits, such as those related to unpaid bills for medical and utility services (again, imperfectly). Although public records include some details about the action, the information available is narrower in scope than that available on credit accounts.

Overall, about 12 percent of the individuals in the credit reporting company data had at least one public record item (percentage derived from table 1), and almost 37 percent of the individuals with a public record item had more than one item noted. Judgments and liens, representing 40 percent and 34 percent of the public records respectively, were the two most common types of public record noted in the data

27. Other bankruptey chapters available to individuals, but rarely used by them, include Chapter 11 and Chapter 12. For more information on bankruptcy, see "Bankruptcy Basics," Administrative Office of the United States Courts, June 2000. sample (table 10). Bankruptcies accounted for nearly all the remaining public records. Most of the bankruptcy records were associated with Chapter 7 filings, which is the most common type of personal bankruptcy. $^{28}$

Lawsuits and foreclosures accounted for small proportions of the public record actions included in the data because credit reporting companies choose to gather such information only in limited circumstances. Underlying this decision for lawsuits is a belief that the simple filing of a lawsuit, which precedes any decision on its merits, is of only limited value, particularly for credit evaluation. Moreover, as shown below, the degree to which lawsuits are reported is inconsistent. Credit reporting companies generally do not gather such information for foreclosures because most of them are believed to have already been reported in conjunction with credit accounts; thus, collecting them from public records would be redundant.

The public records information was examined to determine the types of plaintiffs involved in these actions. Almost all the liens recorded in the data

28. Andrea Stowers and Mark Cole, "A Bankruptcy Wake-Up Call," Mortgage Banking, vol. 57, no. 5 (February 1997), pp. 10-17. 
involved federal or state governmental entities; local governments and others accounted for only about 6 percent of the liens. For both judgments and lawsuits, the most common types of plaintiffs were those in the "other" category (mostly smaller retailers and law firms), followed by creditors (large retailers, banking institutions, and finance companies) and providers of medical services.

A large proportion of the public record items associated with liens, judgments, and lawsuits showed relatively small balances owed (table 10). About onequarter of these three types of public record items in the credit reporting company data showed no balances owed, indicating that the legal action was either paid in full or resolved in some other manner. About 35 percent of the public records of these types showed an amount owed of $\$ 1,000$ or less; about 7 percent involved actions seeking more than $\$ 10,000$. Unlike the other types of public records (excluding bankruptcies), foreclosures typically showed large dollar amounts owed. While about onefifth of the foreclosures showed no balances currently owed (the foreclosure action was either "satisfied" or "dismissed"), nearly three-quarters involved balances of $\$ 10,000$ or more.

In some cases, more than one public record item for an individual appears to be associated with a single episode. The reasons for several public record items resulting from a single episode are various. Failure to pay a bill may cause both a lawsuit and a judgment to appear in an individual's records. Several public records related to unpaid medical bills may stem from the same injury or illness. An appealed judgment or a refiling of a judgment in a different court may result in more than one record of a judgment. In addition, the records for an individual may show a state or local tax lien that has not been paid and a separate record of a paid tax lien of the same type, but these may or may not refer to the same original lien.

To the extent that case identifiers (docket numbers) are available, credit reporting companies use them to update public record information. For example, if a tax lien is reported paid with the same docket number used for the original public record of the lien, the original record will be updated by showing the status as paid rather than by adding a new lien item to the consumer's record. Consistent case identifiers are not always available, however; for example, new docket numbers may be assigned when a judgment is appealed. In such circumstances, two or more distinct records for the same episode may appear in the data. Determining whether distinct public record items pertain to the same episode is difficult.
To shed light on this issue, the authors developed some rules of thumb to estimate the extent to which multiple public record items are related. In the case of public records associated with medical bills, for example, the authors considered all records that did not show a substantial gap between the dates of each record to be a single episode. In the case of bankruptcies, if a record of an initial filing under Chapter 13 was followed shortly thereafter by a filing under Chapter 7 , both records were considered a single episode. The actual incidence of unique episodes may be higher or lower than these estimates.

Excluding liens, the number of unique episodes is estimated to be about 90 percent of the total number of public records, with little variation across the types of public records. For liens, the number of unique episodes is estimated to be about two-thirds of the total number of public records of this type; but determining what is a unique incident is more difficult. For example, multiple liens filed at the same time by the same type of governmental entity may be liens for the same tax year or pertain to different years.

Patterns in the public records in the sample suggest some inconsistency in reporting across plaintiffs and geographic areas. For example, the inconsistent capturing of lawsuits is reflected in the sample by the fact that three states (Maryland, New York, and Pennsylvania) accounted for two-thirds of all individuals with records of lawsuits. Inconsistencies can arise not only because of reporting practices but also because of the practices of specific plaintiffs. Some plaintiffs, for example, obtain separate judgments for individual unpaid billed items, whereas other plaintiffs in similar circumstances may have combined the bills.

\section{Collection agency accounts}

Information on non-credit-related bills in collection, such as those for unpaid medical services, is reported to credit reporting companies by collection agencies. In addition, collections on some credit-related accounts also are reported directly by collection agencies. In the latter case, the information is grouped with the collection actions on non-credit-related bills rather than with the credit account information. Overall, about 31 percent of the individuals with credit reporting company records had at least one such collection action reported by a collection agency (derived from table 1). For about 10 percent of the individuals, the only record item in their credit reporting company file was a collection agency action. Because collections are considered to be a type of major derogatory, they can have an important effect 
11. Collection actions reported by collection agencies, grouped by type of collection and distributed by amount originally owed

Percent

\begin{tabular}{|c|c|c|c|c|c|c|c|c|c|c|}
\hline \multirow[t]{2}{*}{ Type of collection } & \multirow{2}{*}{$\begin{array}{l}\text { Share of } \\
\text { collections }\end{array}$} & \multicolumn{7}{|c|}{$\begin{array}{c}\text { Amo.mt originally ored } \\
\text { (dibllars) }\end{array}$} & \multicolumn{2}{|c|}{$\begin{array}{l}\text { Meno: } \\
\text { Amount originally ow ict } \\
\text { on collect on action } \\
\text { (dol its) }\end{array}$} \\
\hline & & $1-100$ & $101-250$ & $251-500$ & $501-1,000$ & $1,001-5,000$ & $\begin{array}{c}5,000 \\
\text { or more }\end{array}$ & Total & Mean & Median \\
\hline \multirow{8}{*}{ 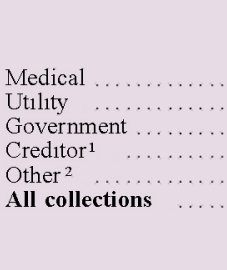 } & \multicolumn{10}{|c|}{ All collecitins } \\
\hline & 52.2 & 36.5 & 33.3 & 16.2 & 8.3 & 4.8 & .9 & 100 & 386 & 142 \\
\hline & 22.7 & 24.7 & 34.2 & 23.6 & 12.3 & 5.1 & .2 & 100 & 342 & 199 \\
\hline & 2.3 & 29.3 & 33.9 & 15.9 & 13.8 & 6.2 & 1.0 & 100 & 466 & 199 \\
\hline & 5.8 & 19.6 & 18.4 & 10.9 & 11.2 & 30.4 & 9.4 & 100 & 1,699 & 587 \\
\hline & 16.9 & 45.7 & 249 & 11.9 & 8.6 & 8.1 & 9 & 100 & 425 & 116 \\
\hline & 100.0 & 34.2 & 31.2 & 16.8 & 9.5 & 7.0 & 1.2 & 100 & 463 & 156 \\
\hline & \multicolumn{10}{|c|}{ |'aid-coll" collecitions } \\
\hline Medical. & 54.5 & 13.3 & 11.5 & 10.2 & 9.5 & 7.3 & 5.2 & 11.5 & n.a. & n.a. \\
\hline Ut 11 ty $\ldots$ & 22.7 & 14.6 & 13.0 & 9.1 & 5.5 & 3.7 & 4.2 & 11.1 & n.a. & n.a. \\
\hline Government . & 2.9 & 20.8 & 13.6 & 9.2 & 9.4 & 4.1 & 6.0 & 13.8 & n.a. & n.a. \\
\hline Creditor $^{1} \quad \ldots$. & 3.1 & 11.8 & 6.5 & 7.2 & 4.1 & 3.4 & 1.3 & 5.9 & n.a. & n.a. \\
\hline \multirow{2}{*}{$\begin{array}{l}\text { Other }{ }^{2} \\
\text { All paid-off } \\
\text { collections }\end{array}$} & 16.8 & 12.4 & 11.3 & 10.3 & 8.0 & 6.2 & 6.0 & 11.0 & n.a. & n.a. \\
\hline & 100.0 & 13.4 & 11.7 & 9.8 & 7.7 & 5.4 & 3.5 & 11.1 & n.a. & n.a. \\
\hline
\end{tabular}

on the consumer's ability to obtain credit or on the price of such credit.

Unlike credit accounts, but like public records, collection actions are reported without a code indicating the type of original creditor. The data, however, do include information that can be used to infer the type of entity that originally sought the collection. By the authors' estimates, most collection actions reported by collection agencies do not involve credit accounts; only about 6 percent are related to credit accounts (table 11). The majority of collection actions (about 52 percent) are associated with medical bills. The high incidence of collections related to medical bills is not surprising given both the large number of individual consumers and families that have partial or no health insurance coverage and the high cost of many medical services. ${ }^{29}$ The second largest category involved collection actions for unpaid bills for utility services, which by the authors' analysis, account for about 23 percent of all collections.

Most collection actions reported by collection agencies showed small balances owed when originally reported to the credit reporting company. About 34 percent of all the collections involved an original amount owed of $\$ 100$ or less, and 82 percent

29. According to the Federal Reserve's 2001 Survey of Consumer Finances, about 9 percent of households had no public or private health insurance coverage, and nearly 17 percent had only partial coverage, meaning that one or more members of the household had no coverage. These proportions are little changed from those found in the 1998 Survey of Consumer Finances. involved an amount $\$ 500$ or less. Overall, the mean and median amounts originally owed were $\$ 463$ and $\$ 156$, respectively. Credit-related actions in the collection records involved substantially larger amounts: The mean and median amounts reported by collection agencies for credit accounts equaled nearly $\$ 1,699$ and $\$ 587$, respectively. The data also show that only about 11 percent of the reported collection items have been paid off (table 11, bottom panel), with collections filed by a governmental entity the most likely and credit-related collections the least likely to have been reported as fully paid.

As with the public records, individuals sometimes have more than one collection agency action reported. About 44 percent of the individuals with a collection agency record had more than one item noted. Like tracking public records, tracking collection agency accounts to update their status is not always possible because of changes in account numbers that sometimes result from transfers of the account across collection agencies. Also, as noted for public records items, more than one collection agency action for an individual may stem from the same episode (for example, one medical incident involving several component billings), and determining whether distinct record items pertain to the same episode is difficult. Some rules of thumb were used to identify the extent to which multiple collection agency items were related. The estimated number of unique episodes is about 70 percent of the total number of collection agency records. 
As with public records, multiple collection actions associated with the same incident appear in a number of cases to result from the practice of a particular plaintiff's submitting separate collections for different billed items. Since another plaintiff in similar circumstances might have combined the bills into a single collection, inconsistencies can arise in the way collection actions are counted across individual credit records. Moreover, a small proportion of the collection records appear to be due to a repeat filing of the same action with the credit reporting company.

\section{Inquiries}

Credit reporting company records include information about inquiries made about a consumer's credit history. These inquiries are conducted to ensure that an applicant for credit, apartment rental, insurance, or employment has a background that meets the minimum standard the inquirer has established for providing the service. The data do not include inquiries made by creditors about existing accounts or inquiries made by consumers themselves. This finding is consistent with the view that credit underwriters focus primarily on a consumer's recent efforts to obtain credit.

Overall, about 58 percent of the individuals in the credit reporting company sample had at least one inquiry noted in their files. The inquiries are often bunched in time. About 26 percent of the inquiries were made within one week of another inquiry that appears in a given individual's credit file, and about 60 percent were made within one month of another inquiry in the file. These figures are consistent with the view that consumers often engage multiple parties when seeking a service, such as a loan or an apartment; for example, a consumer purchasing a car or home may approach more than one creditor while shopping for the best available terms to finance the purchase. However, because fewer than 2 percent of the records of inquiries included information about the purpose of the inquiry, it is impossible to determine with certainty if bunched inquiries represent shopping for a single loan purpose or requests for different loan products (for example, a mortgage and a credit account to purchase household items). Nevertheless, credit evaluators use various techniques to differentiate between these two circumstances. One technique, for example, is to use the type of creditor as a proxy for the loan type and the timing of the inquiry to identify multiple inquiries arising from shopping for a single loan.

\section{DATA ISSUES AND POSSIBLE RESOLUTIONS}

Credit reporting companies gather information to develop a comprehensive and contemporaneous picture of the ongoing and past credit relationships of individuals, primarily to facilitate credit evaluation. Examination of a sample of this information reveals the breadth of the data contained in credit report files. Each individual's credit record provides a detailed snapshot of that person's current use and past experiences with credit, as well as information on public records and collection accounts. Credit records contain dozens of items, ranging from the type, source, and amount of credit borrowed to the payment patterns associated with the repayment of such debt. Thus, the records enable one to construct diverse indicators of credit use and repayment performance, including measures of credit utilization, numbers of recently opened accounts, and timing and severity of payment problems. The breadth and timeliness of the data included in credit reporting company records hold the promise that such information may provide a new source of information for the Federal Reserve.

Available evidence indicates that these data and the credit-scoring models derived from them have substantially improved the overall quality of credit decisions and have reduced the costs of such decisionmaking. ${ }^{\text {:0 }}$ Almost certainly, consumers would receive less credit and the price of the credit they received would be higher, if not for the information provided by credit reporting companies. Moreover, the credit reporting system has become more comprehensive over the past decade with notable improvements, such as enhanced reporting of mortgage credit.

\section{Issues with the Data}

Despite the benefits that the credit reporting system offers, analysis reveals several areas of the current system that could be improved. A close examination of credit reporting company data reveals that the information is not complete, may contain duplications, and at times contains ambiguities about the credit

30. For a recent analysis comparing the efficacy of underwriting decisions conducted judgmentally with the efficacy of decisions reviewed by automated underwriting systems that incorporate credit reporting company data, see Susan Wharton Gates, Vanessa Gail Perry, and Peter M. Zorn, "Automated Underwriting in Mortgage Lending: Good News for the Underserved?" Housing Policy Debate, vol. 13, issue 2, 2002, pp. 369-91; and John M. Barron and Michael Staten, "The Value of Comprehensive Credit Reports: Lessons from the U.S. Experience," Credit Research Center, Georgetown University, 2002 . 
histories of at least some consumers. The following are four particular areas of concern: (1) credit limits are sometimes not reported; (2) the current status of accounts that show positive balances but are not currently reported is ambiguous; (3) some creditors fail to report nonderogatory accounts or minor delinquencies; and (4) the reporting of data on collection agency and public record accounts is possibly inconsistent and inquiry data is incomplete.

Missing credit limits. A key measure used in credit evaluation-utilization-could not be correctly calculated for about one-third of the open revolving accounts in the sample because the creditor did not report the credit limit. About 70 percent of the consumers in the sample had a missing credit limit on one or more of their revolving accounts. If a credit limit for a credit account is not reported, credit evaluators must either ignore utilization (at least for accounts without limits) or use a substitute measure such as the highest-balance level. The authors' evaluation suggests that substituting the highest-balance level for the credit limit generally results in a higher estimate of credit utilization and probably a higher perceived level of credit risk for affected consumers.

Accounts not currently reported. About 8 percent of all accounts in the sample showed positive balances but were not currently reported. Moreover, of those accounts reported as a major derogatory at the mostrecent report, almost three-fifths were not currently reported. The authors' evaluation suggests that many of these accounts, particularly mortgages and installment loans, are likely to have been either closed or transferred but were not reported as such. Many of these accounts were reported by creditors that were not reporting data to the credit reporting company when the sample was drawn, and thus information on these accounts is unlikely to have been updated. The significant fraction of not currently reported accounts that are likely closed or transferred implies that some consumers will show higher current balances and a larger number of open accounts than they actually hold. Some of this overrepresentation is mitigated by credit evaluators' assumption that accounts unreported over a long period are closed. However, they may not make the assumption for derogatory accounts, thus penalizing consumers who have paid off a delinquent account since it was last reported.

Failure to report nonderogatory accounts or minor delinquencies. Between 1 percent and 2 percent of the credit reporting company records were supplied by creditors that reported information only on credit accounts that had experienced payment problems. The evidence does not indicate that the accounts they did report were in error; however, the failure to report accounts in good standing likely affected the credit evaluation of consumers with such accounts. If consumers have low utilization of nonreported accounts, the failure to report may worsen their credit evaluation. For consumers having nonreported accounts with high utilization, however, the failure to report may actually improve their credit evaluation. The analysis further indicates that some creditors do not report that an account is experiencing a minor delinquency. The credit histories for consumers with such accounts appear somewhat better than they actually are.

Inconsistent reporting of 'public records, collection agency accounts, and inquiries. About 40 percent of the individuals with public records have more than one such record, and a similar percentage of those with accounts reported by collection agencies have more than one collection item. For many of these individuals, the multiple record items appear to pertain to the same episode, such as one record filed when a collection action was initiated and a second record filed when it was paid. Evidence indicates that some inconsistencies arise in the reporting of actions across geographic areas or types of plaintiff. Moreover, unlike the credit account data, no code identifies the type of creditor or plaintiff. These limitations of the data could significantly affect credit evaluation because more than 50 percent of the records of major derogatories in the credit files are collection agency reports or public records.

Multiple inquiries in a consumer's credit file can arise either when the consumer shops among different creditors for the same loan or when he or she applies for multiple loans. Credit evaluators would like to distinguish between these different circumstances because the latter may indicate financial distress, whereas the former would not. Although the presence of a code for loan type in the credit file's inquiry records holds the promise of distinguishing between the circumstances, more frequent reporting by creditors is required for these codes to serve their purpose. Creditors failed to provide the code for 98 percent of the inquiry records in the data sample. In the absence of a loan-type code, proxies, such as the type of creditor, would have to be used to distinguish between shopping for a single loan and applying for multiple loans. 


\section{Consequences of Data Limitations}

The effect of these data limitations is twofold. First, because credit-scoring models are built using these data, ambiguities, duplications, and omissions will affect the model's assessments of risk factors. For example, if one cannot distinguish in the data between individuals who have a certain characteristic (say, an unpaid major derogatory) from those who appear to have that characteristic but actually do not (such as those with an unreported payoff), then the model will incorrectly assign a risk factor to the joint group that reflects their combined performance. Second, ambiguities, duplications, and omissions in credit files can result in an incorrect evaluation of the credit risk of individual applicants. These two effects are intertwined: Correcting one part without the other will not fully solve the problem. For example, resolving the problems in applicant files will not correct the models if the models were developed using problematic data.

Such limitations in credit reporting company records have the potential to both help and hurt individual consumers. On the one hand, consumers with positive account information, such as the payoff of a major derogatory, that creditors have not reported are hurt. On the other hand, consumers with negative information that is unreported, such as an unpaid medical bill that does not go to collection or an unreported minor delinquency on a credit account, are helped. Even consumers with no such problems in their files can be affected. For example, a consumer with an unpaid major derogatory that is correctly reported will look the same as a consumer with a paid, but not updated, major derogatory. As a consequence, the former consumer will likely have a somewhat better credit evaluation, and the latter consumer a somewhat worse one, than he or she would if: credit grantors (and the builders of the models they use) were better able to distinguish between paid and unpaid major derogatories.

Consumers who are hurt by ambiguities, duplications, and omissions in their files have an incentive to correct them, but consumers who are helped by such problems do not. The result of this difference may be an asymmetric correcting of files. Such asymmetry can lead to overall performance on loans that is somewhat worse than would be predicted by creditscoring models.

\section{Possible Remedies}

A remedy for many of these issues is consumer vigilance. Consumers can periodically review their

\section{How to Contact the National Credit Reporting Companies}

The following is the contact information for the three national credit reporting companies.

\section{Equifax}

P.O. Box 740241

Atlanta, GA 30374

(800) 685-1111 (order credit report)

(888) 766-0008 (fraud alert)

http://www.equifax.com

Experian

P.O. Box 2002

Allen, TX 75013

(888) 397-3742 (order credit report, disputing credit items, fraud alert, other questions)

$\mathrm{http} / / / \mathrm{www}$.experian.com

Trans Union

Trans Union Consumer Relations

P.O. Box 2000

Chester, PA 19022

(800) 916-8800

To order a credit report:

Trans Union LLC

Consumer Disclosure Center

P.O. Box 1000

Chester, PA 19022

http://www.transunion.com

credit reports and use the dispute process established in the FCRA to correct errors or omissions (see box "How to Contact the National Credit Reporting Companies"). The FCRA generally provides that a consumer who is denied credit must be given the reasons for denial and an opportunity to receive a copy of his or her credit report without charge. Similarly, consumers seeking new credit are routinely advised to check their credit reports before applying. In addition, when credit is underwritten, a loan officer sometimes reviews the credit report information and thus may have an opportunity to see and correct data problems.

The extent to which the concerns noted above are likely to be addressed by individual consumers or loan officers checking credit reports is unclear. On the one hand, an unreported credit account, credit limit, or inquiry loan-type code may not be identified as an issue of concern. Moreover, the credit granting system has moved toward risk-based pricing in which applicants are less likely to be denied credit (and thus given the reasons for denial) than to receive credit 
at prices that reflect the perceived risk. Consumers may not always be aware that they are paying higher prices for the credit. Similarly, an increasing share of consumer revolving credit is obtained through pre-approved solicitations as opposed to consumerinitiated requests for credit. On the other hand, both growing consumer awareness of the importance of credit reports and easier consumer access to credit reports and credit scores serve to increase consumer vigilance.

The credit reporting companies also could address some of the issues identified above. For example, developing a plaintiff code system for collection and public records would allow credit evaluators to differentiate among different types of these records in assessing credit risk. Similarly, expanding stale account rules and identifying accounts of creditors that are no longer reporting information to the credit reporting companies would assist credit evaluators in determining how much weight to give not currently reported accounts.

Most of the problems cited above result from the failure of creditors, collection agencies, or public entities to report or update items - areas that are beyond the direct control of the credit reporting companies. Thus, fully resolving these problems requires a more comprehensive and consistent reporting system, particularly with regard to major derogatories, collection agency accounts, and public records. Some changes in this vein are happening already. For example, only about 13 percent of revolving accounts now being reported to the credit reporting company that supplied the data are missing credit limits. This reduction from the 33 percent incidence at the time the sample used for this evaluation was drawn (1999) occurred in part because of pressure on creditors by the credit reporting companies and others.
In the interim, some steps might be considered to mitigate or reduce the effect of the problems noted above. Credit evaluators might develop models that identify individuals whose credit files are likely to contain data problems. Factors such as missing credit limits, not currently reported accounts, and duplicative collection accounts or public records may be good indicators of individuals whose credit scores are potentially less predictive. Creditors might judgmentally review actions on applicants estimated to have a high likelihood of significant error, particularly those whose credit scores place them in a range in which the price or availability of credit is likely to be affected. Such reviews, with the potential to gather more information from the consumer, may be able to resolve problems in the credit evaluations for identified borrowers.

In reflecting on these data limitations and remedies, several issues should be kept in mind. First, although some problems in the credit reporting data that are likely to affect the credit evaluation of individuals have been identified, it is very difficult to determine the extent to which credit availability would change if these problems were addressed. It is likely that data issues will materially affect the availability and pricing of credit only for those individuals of marginal creditworthiness. Second, the costs of correcting the identified data problems have not been evaluated. Some of the problems may be very difficult and expensive to overcome, and in some cases the costs may exceed the benefits. Finally, this analysis rests on the experiences of only one of the three national credit reporting companies and uses data that are now somewhat dated. Many changes are taking place in the credit reporting industry, and they may mitigate some or all of the highlighted limitations. 